\title{
Relation of Carlin-type gold mineralization to lithology, structure and alteration: Screamer zone, Betze-Post deposit, Nevada
}

Received: 1 July 2001 / Accepted: 24 January 2002 / Published online: 3 May 2002

(C) Springer-Verlag 2002

\begin{abstract}
An evaluation of the relation between geologic features and gold grade has been undertaken in the Screamer zone of the Betze-Post deposit, the largest Carlin-type gold deposit in the world. Screamer, which forms the western end of Betze-Post, is a stratiform ore zone that is hosted almost entirely by the wispy member of the Popovich Formation. The wispy member is overlain by the planar member of the same formation and underlain by the Roberts Mountains Formation, both of which contain much smaller amounts of gold mineralization in the Screamer zone. Geologic features recognized at Screamer reflect the long history of events that have affected the area since mid-Paleozoic time. The two earliest events at Screamer were probably sulfidation and formation of flat fractures, and the two latest events were pyritization and formation of kaolinite-filled fractures, which took place at least partly during gold mineralization. Gold mineralization at Screamer shows ambiguous relations to most lithologic, alteration and structural features. For instance, gold grades in the wispy member of the Popovich Formation are slightly higher in rock units that contain the largest proportion of debris flow material, but this relation does not account for most ore. The correlation of gold grades with fracture density is also generally poor, but gold grades are slightly higher in samples containing vertical and/or kaolinite-bearing fractures, particularly those with a northeasterly trend. Most early veins at Screamer are
\end{abstract}

Editorial handling: R.J. Goldfarb

Z. Ye $\cdot$ S.E. Kesler $(\bowtie) \cdot$ E.J. Essene

Department of Geological Sciences,

University of Michigan, Ann Arbor, MI 48105, USA

E-mail: Skesler@umich.edu

P.B. Zohar

Barrick Goldstrike Mines, Inc. P.O. Box 29,

Elko, NV 89803, USA

J.L. Borhauer

SNC Lavalin America, Inc., P.O. Box 29,

Elko, NV 8903, USA horizontal and most later veins are vertical, suggesting that the long-term trend of fluid pressures in the area has been from lithostatic to hydrostatic. Finally, gold grades correlate poorly with silicification and decarbonatization, and although some gold appears to be associated with rock containing kaolinite, much is not. The only rock feature that shows a direct relation to gold grade is pyrite. Some pyrite formed by sulfidation of the original rock, but much of it formed by addition of pyrite to the rock. Stability limits for ore and alteration assemblages at Screamer indicate that pressures of mineralization were probably not less than about 300 bar, which require depths of about $3 \mathrm{~km}$ for the hydrostatic conditions that probably prevailed in the Betze-Post hydrothermal system.

Keywords Betze-Post deposit · Carlin · Gold · Nevada

\section{Introduction}

The relation between gold grade and geologic features, particularly wall rock alteration, remains poorly understood in Carlin-type deposits (Arehart 1996). These deposits have been divided into four groups based on their geologic setting (Teal and Jackson 1997). In three of these groups, structure appears to control the location of ore, and in the remaining group stratigraphy and lithology are the main controlling geologic features. Ore controls in the Screamer zone, which is the subject of this report, are most obviously related to stratigraphy and lithology. Such deposits offer the best opportunity to determine whether wall rock alteration reactions are an important cause of gold deposition in Carlin-type deposits. Alteration reactions that have been observed in these deposits and that might cause gold deposition include silicification, decarbonatization, kaolinization, illitization, and sulfidation. In previous studies, mineralization has been linked mainly to decarbonatization and silicification (Kuehn and Rose 1992), illitization 
(Drewes-Armitage et al. 1996), and sulfidation (Hofstra et al. 1991; Stenger et al. 1998; Hofstra and Cline 2000).

Recognition of geologic features related to gold mineralization is complicated by the long history of hydrothermal events that has left a complex trail of overlapping alteration and mineralization in rocks of the Carlin Trend. The earliest of these, which occurred in Late Devonian time, was caused by basinal brine migration (Emsbo et al. 1998, 1999; Emsbo 2000). This was followed by Late Jurassic intrusion-related alteration and mineralization (Arehart et al. 1993; Emsbo et al. 2000), and then Cretaceous and late Eocene alteration and mineralization of uncertain parentage (Arehart et al. 1993; Emsbo et al. 1996; Drewes-Armitrage et al. 1996; Hofstra and Cline 2000; Ressel et al. 2000). The Screamer zone is partially within the metamorphic aureole of the Jurassic Goldstrike stock (Fig. 1) and is near the Miekle deposit where Devonian effects are widespread, and, thus, has been affected by most or possibly all of these events. In this study, we describe geologic features of the Screamer zone of the Betze-Post deposit and investigate their relation to gold mineralization and to formation of Carlin-type deposits. Because Screamer was not exposed by mining at the time of this study, all work is based on samples and logs from drill core. The distribution of holes from which samples for this study were obtained is shown in Fig. 1, and data on the lithology, structure, and bulk composition of these samples are provided in the

Fig. 1 General geologic map of the Betze-Post deposit showing location of longitudinal cross section. Location is also shown for drill holes as described in the Appendix (1-27) as well as other holes not listed there, including 28-SJ552C, 29-SJ423C, 30-RM98-6C (modified from Leonardson and Rahn 1996; and Barrick geology staff). UTM coordinates are given in feet. Inset shows location of the Carlin Trend in Nevada (Miekle deposit is at north end of Carlin Trend)
Appendix. Although we were hampered by a lack of material suitable for geochronologic measurements, paragenetic relations provide some insights into the relation between the features seen in this study and the hydrothermal events listed above.

\section{Geologic setting and features of the Betze-Post deposit}

Screamer is in the northern part of the Carlin Trend in northeastern Nevada (Fig. 1) and is the western and most distal part of the Betze-Post deposit, the largest gold deposit in North America (Teal and Jackson 1997). Although small ore zones in the upper part of the BetzePost system were mined during the 1960s and 1970s, its large size was recognized only when deep exploration drilling in the mid-1980s discovered the Post and Betze parts of the deposit (Bettles 1989; Arehart et al. 1993). Screamer was discovered by further deep drilling in 1987 (Tousignant in Teal and Jackson 1997). As of December 1996, combined production and reserves in the Betze-Post deposit, including the Screamer zone, consisted of about 157 million short tons of ore containing 34,202,124 oz of gold (Teal and Jackson 1997, Appendix). Of this total, about 4 million ounces are contained in the Screamer zone (Tousignant in Teal and Jackson 1997).

Screamer is in a lower Paleozoic sedimentary rock package that has been divided into two parts. The autochthonous sequence, which hosts mineralization in the Carlin area, consists mainly of the SilurianDevonian Roberts Mountains Formation (470 m thick), Devonian Popovich Formation (400 $\mathrm{m}$ thick) and Devonian-Mississippian Rodeo Creek unit (50 to $250 \mathrm{~m}$ thick; Volk et al. 1996). These are overlain by an

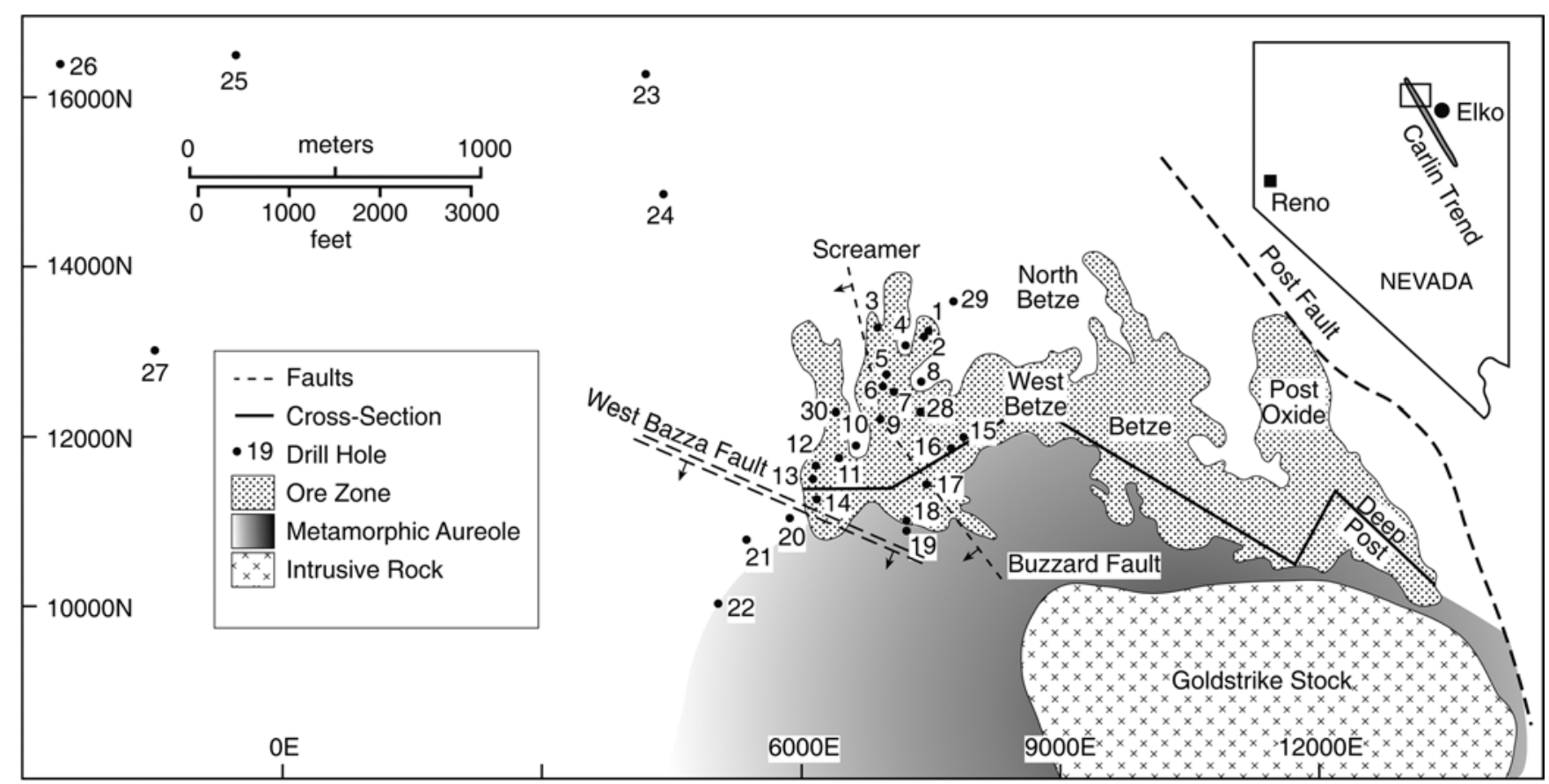


allochthonous sequence consisting largely of the Ordovician Vinini Formation, which was thrust over the younger sediments during Late Devonian-middle Mississippian time along the Roberts Mountains thrust (Roberts et al. 1958). Additional ore is found in the Jurassic Goldstrike stock, which cuts this sequence just south of the Betze-Post deposit (Fig. 2). Jurassic and Eocene stocks and felsic dikes cut the entire Paleozoic sequence in and near the Betze-Post deposit, and all

Fig. 2 Top Longitudinal cross section through the Betze-Post deposit showing geologic setting of the ore zone. Rectangle at lower left shows location of detailed cross section. Bottom Detailed cross section through the Screamer zone of the Betze-Post deposit showing divisions of the Popovich and Rodeo Creek Formations that are discussed in the text (from Barrick geology staff). Horizontal scale is not shown because orientation of section line varies from point to point. Approximate scale is shown by UTM coordinates, which are given in feet rocks are overlain by volcanic and sedimentary rocks of Mesozoic and Cenozoic age (Arehart et al. 1993; Teal and Jackson 1997; Ressel et al. 2000).

In the immediate vicinity of the Betze-Post deposit, the entire Paleozoic sequence has been folded into a series of doubly plunging, north- to northwest-striking anticlines that control the distribution of mineralization (Arehart et al. 1993; Leonardson and Rahn 1996; Ferdock et al. 1997). Along the eastern margin of the Betze-Post deposit, stratigraphic units dip steeply into the Post fault and they become more flat-lying towards the west. Mineralization in the Betze-Post system consists of vertically stacked, tabular ore zones that follow favorable stratigraphic units and are separated by less permeable horizons (Fig. 2). Overall thickness of mineralization decreases from east to west in the system, as the degree of stratigraphic control increases. In the
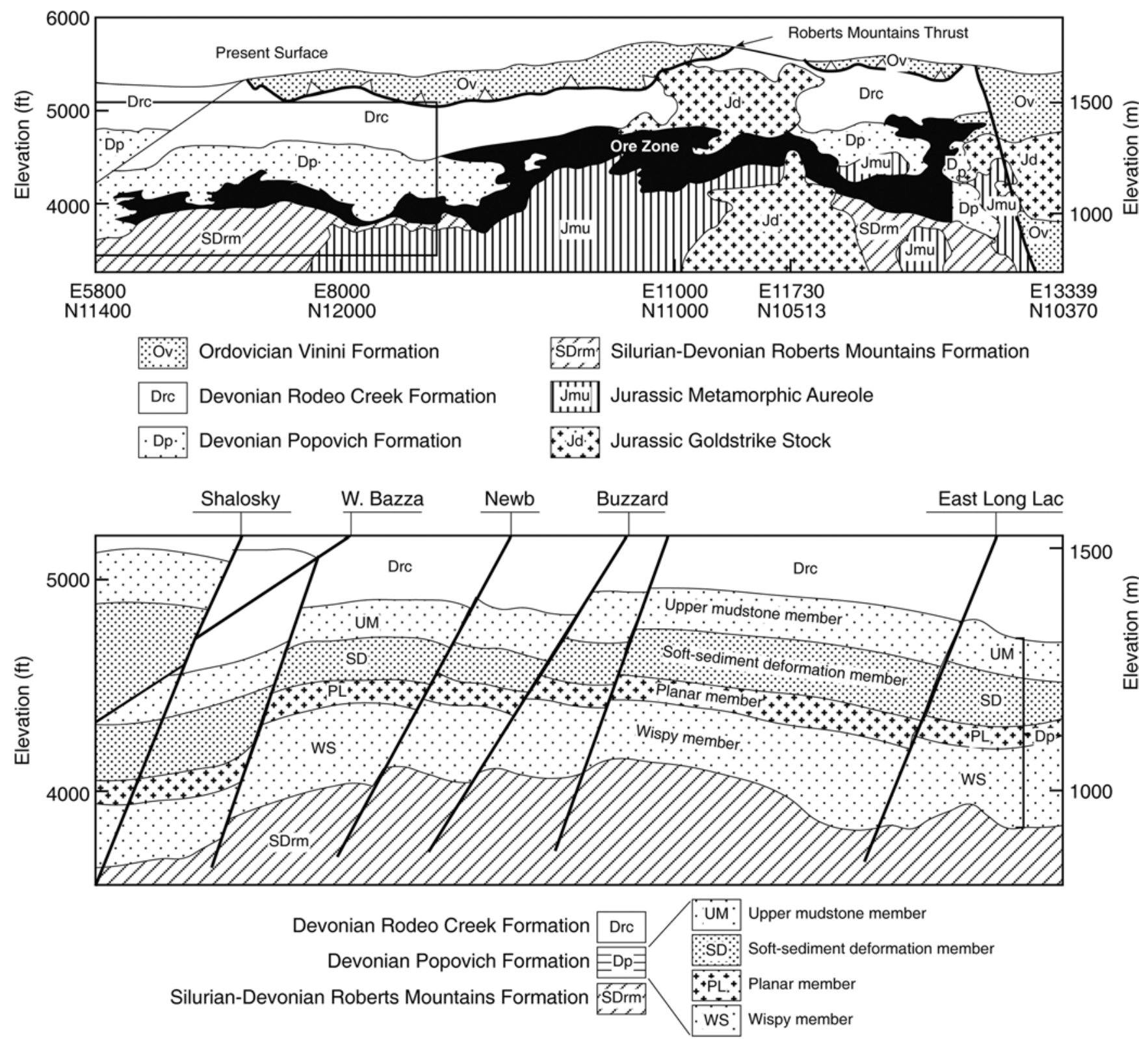
east, the Post part of the Betze-Post deposit consists of the upper Post Oxide section in rocks of the Rodeo Creek unit and Vinini Formation and the Deep Post section in rocks of the Popovich and upper Roberts Mountains Formations. Toward the west, ore in the Betze part of the deposit consists of as many as five vertically stacked, generally tabular ore zones that follow favorable stratigraphic horizons, mainly in the Popovich Formation.

Farther to the west, mineralization in the Screamer zone is strongly controlled by stratigraphy relative to Betze, and particularly Deep Post. Mineralized stratigraphic units in this part of the section include the Roberts Mountains Formation and the overlying four members of the Popovich Formation (Fig. 2). The lowermost of these Popovich members is the wispy (WS) member, which consists of 70 to $100 \mathrm{~m}$ of laminated calcareous silty limestone, debris flows, and a wide range of other breccias. The silty limestone is characterized by discontinuous, arcuate laminations that are interpreted to be the result of burrowing and bioturbation, and the debris flows are composed of peloidal bioclastic wackestones (Armstrong et al. 1997). In addition to the debris flows, the wispy member contains a wide variety of fragmental rocks and breccias of both sedimentary and tectonic origin. Decalcification along tabular beddingparallel layers and fractures is common in the Betze ore zone and similar breccias are present in the stratigraphic section of the Screamer zone (Leonardson and Rahn 1996; Peters et al. 1997).

The wispy member is overlain by the planar-laminated mudstone member (PL, $30 \mathrm{~m}$ thick), which consists of laminated calcareous mudstone and muddy limestone with abundant fine-grained fossil hash beds and more regular layering than seen in the wispy member. Graptolites are common in the upper few meters of this member. Mineralization is also found locally in the planar member. Above the planar member is the soft sediment deformation member (SD, 50 to $80 \mathrm{~m}$ thick), a thin to thick-bedded micritic limestone with zones of soft sediment deformation characterized by slump or "fuzzy-top" bedding and matrix-filled debris flows (Armstrong et al. 1997). These units are overlain by the upper mudstone member (UM, 40 to $60 \mathrm{~m}$ thick) of the Popovich Formation.

In contrast to the increasing degree of stratigraphic ore control from east to west in the Betze-Post deposit, structural features decrease in importance in that direction. Local drag folds are found along reverse faults such as the West Bazza (Fig. 1), but the amount of folding is small and most bedding at the Screamer zone has dips of 5 to $10^{\circ}$. High-angle faults, as indicated by drill data, appear to be widespread and have trends of northwest to northeast, similar to those found throughout the Carlin Trend (Teal and Jackson 1997). Most of these faults appear to have normal offset and dip about $60-80^{\circ}$, although one reverse fault with an apparent dip of $45^{\circ}$ has been recognized (Fig. 2). Major NE-striking faults, which are less common at Screamer, dip W or NW.

\section{Relation of gold grade to host rock lithology}

The strong localization of ore in the wispy member at Screamer raises the question of what lithologic, structural, or alteration features are most closely associated with mineralization. To test such possible associations, we compared gold grade and these features in 58 samples of the wispy member from drill holes throughout the Screamer zone (Fig. 1). Samples were also collected from the underlying Roberts Mountains Formation and the overlying planar member of the Popovich Formation. Comparisons were based on megascopic observations of lithology, structure, and alteration, along with estimates of the intensity of alteration based on wholerock chemical analyses (Appendix). Samples of the wispy member average $13 \mathrm{ppm} \mathrm{Au}$ compared with $2 \mathrm{ppm}$ for the planar member and $0.15 \mathrm{ppm}$ for the Roberts Mountains Formation, confirming the strong localization of gold ore in the wispy member (Appendix).

The wispy member consists of silty limestone, debris flows, and other fragmental rocks and breccias, some of which are associated with mineralization. Classifications of breccias associated with mineralization (Ohle 1985; Sillitoe 1985; Sangster 1988) depend heavily on shape of the breccia body and the variety and distribution of clasts, which are difficult to determine from exploration drill holes. Because of this complication, we divided breccias at the Screamer zone only into sedimentary breccias (most of which are debris flows) and non-sedimentary breccias, including fault, hydrothermal, and polygenetic breccias.

The two main original sedimentary lithologies in the wispy member are silty limestone and debris flow. To determine the relation between these lithologic units and gold mineralization, the percentage of each lithology in all hand samples of drill core from the wispy member was estimated and compared with the gold content of that sample. Samples that consisted mainly of non-sedimentary breccias, as defined above, and/or contain other types of deformational features such as vertical fractures, were excluded. The results of this comparison show that samples with high gold grades are found mainly in rocks that have a high percentage of debris flow material, although this association is not strong (Fig. 3). A similar comparison made using data from drill logs showed that core intervals classified as debris flow have slightly higher gold values than do those classified as wispy limestone (Fig. 4).

\section{Relation of gold grade to structure}

Structural features in the wispy member sample suite include fractures (with no mineral filling), veins, and breccias (with mineral fillings). Breccias were in $17 \%$ of the 58 samples, veins were in $36 \%$, and fractures were in $10 \%$. Because of their relatively low individual 


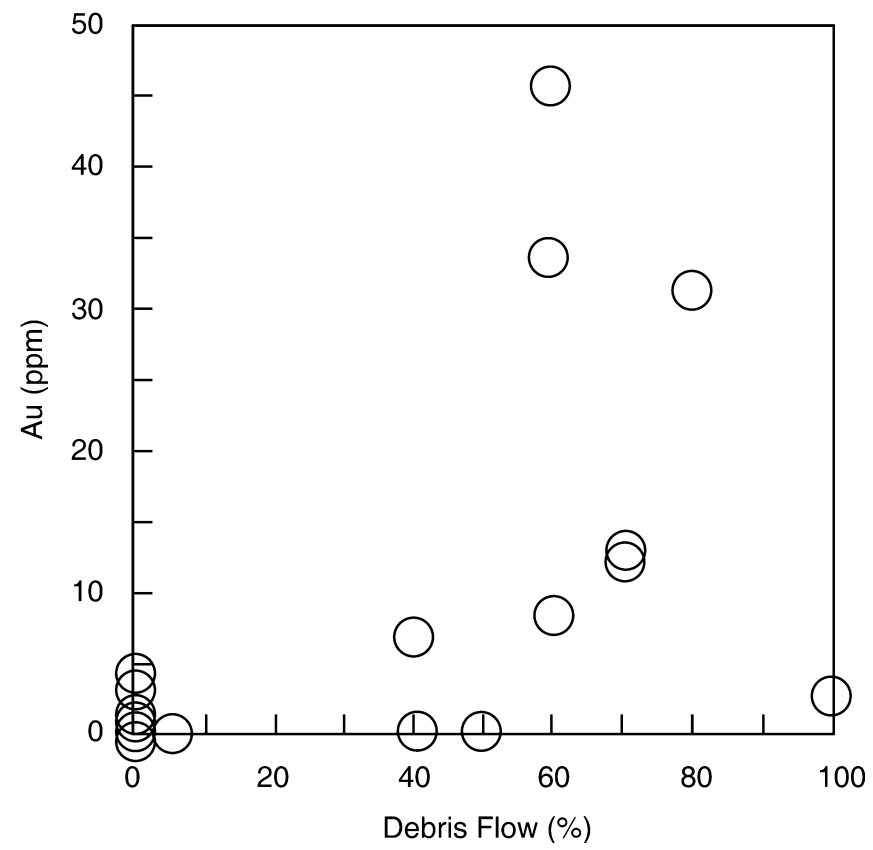

Fig. 3 Relation between percent debris flow in core samples from wispy member and gold content (Appendix)
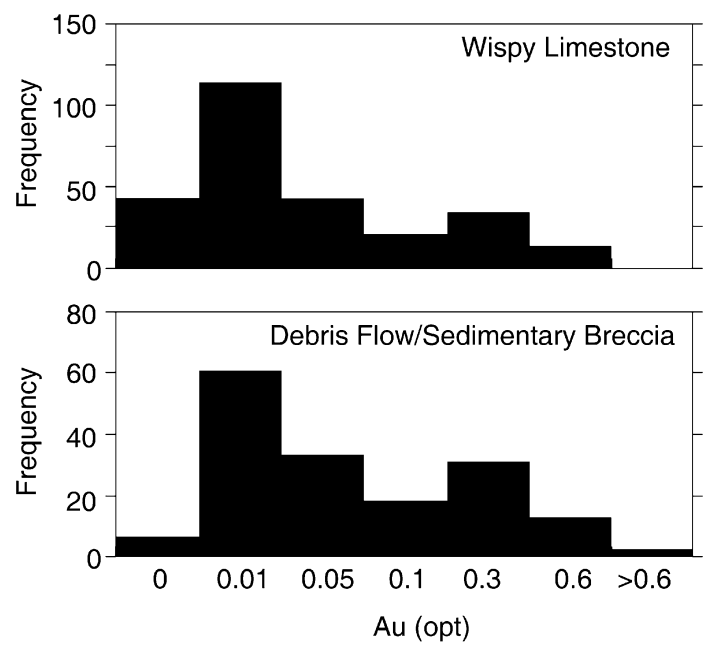

Fig. 4 Distribution of gold grade in 5-foot sections of core consisting of wispy limestone and debris flow from the wispy member as noted for 5 -ft sections in drill logs

abundances, fractures and veins were combined in the following comparisons. Fractures and veins were divided into vertical, inclined, and horizontal groups assuming that the drill core was essentially vertical, and vertical veins generally post-date horizontal or inclined veins. The most common vein mineral is calcite and there appears to have been at least two periods of calcite vein formation. Early calcite veins, some of which contain quartz and dolomite, usually are horizontal and/or inclined and are cut by later vertical veins that contain late calcite with or without kaolinite and/or orpiment, the dominant vein type in our sample suite. Vertical veins containing native gold have also been observed in the western part of the Screamer zone, mainly in the overlying planar member, but veins of this type were not encountered in our sample suite.

We divided wispy member samples into those containing vertical fractures, horizontal or inclined fractures, breccia textures of non-debris flow origin (i.e. possibly tectonic), and no evidence of deformation. Most $(80 \%)$ of the samples from the breccia group have gold grades above $4 \mathrm{ppm}$, whereas $39 \%$ of the samples from the vertical fracture group have grades above $4 \mathrm{ppm}$. None of the group containing fractures with other orientations have gold grades above $4 \mathrm{ppm}$, but $43 \%$ of the samples with no deformation have gold grades above $4 \mathrm{ppm}$. If debris flow samples are removed from the group without fractures, the proportion of samples with gold grades above $4 \mathrm{ppm}$ falls to $1.1 \%$, which is consistent with the correlation suggested above between debris flow lithologies and gold grades.

As a further test of the relation between structure and gold grade, we determined the nature and paragenesis of fractures in 5-foot core intervals through the entire thickness of the wispy member, regardless of whether it was ore-grade or not, in five unoriented drill holes, including three that were mineralized (SJ552C, SJ435C, SJ443C), two that were barren (SJ423C, BZ998C), and one oriented hole (RM986C) that was also mineralized (Fig. 1). Most of these fractures were relatively narrow, only some contained mineral fillings, and intersecting fractures were relatively rare (Fig. 5). Observations on the oriented hole permitted determination of dip and strike of fractures, rather than just their orientation with respect to the axis of the core. Strike and dip angles of fractures in the oriented hole (RM986C) are summarized in Fig. 6, where it can be seen that near vertical and near horizontal fractures are most common. It is not possible to determine the paragenesis of all fractures seen in a drill hole because most do not intersect and, therefore, show no cross cutting relationships. However, it is possible to compare the dip angle of all fractures that do intersect to determine whether there is any systematic change in dip of fractures through time. The difference in dip-angle of two intersecting fractures was calculated by subtracting the dip angle of the older fracture from that of the younger one. As can be seen in Fig. 7, the most common difference obtained by this approach is small and slightly positive. This indicates that early fractures are more likely to have shallow dips (i.e. near horizontal) than later fractures, although the significant number of negative dip angle differences indicates that this evolution from horizontal to vertical fractures was reversed intermittently.

An indication of the importance of fracturing to gold mineralization in the wispy member can be obtained by looking for correlations between fracture abundance and gold grade. Fracture abundance was determined by the one-dimensional method of Haynes and Titley (1980) and Haynes (1984) for 5-ft core intervals in the six core holes that were studied in detail. Overall fracture 
Fig. 5A-D Photographs of fractures and veins. All orientations are given with respect to the core, with vertical fractures being parallel to the length of the core and horizontal fractures being perpendicular to the length of the core. A Inclined calcite-pyrite vein offset by almost invisible vertical fracture (arrow) - SJ423C-1281.4-1282. B Inclined calcite veinlet offset by thicker vertical calcite vein (SJ-552C-881.5). C Inclined quartz-calcite fracture offset by several vertical fractures (RM98-6C-1121.5-1122.2). D Complex fracture array including narrow, almost horizontal calcite-pyrite fracture (arrow) offset by wide, inclined quartz veins that are offset by narrower, almost vertical quartz veins (SJ-552C-834)
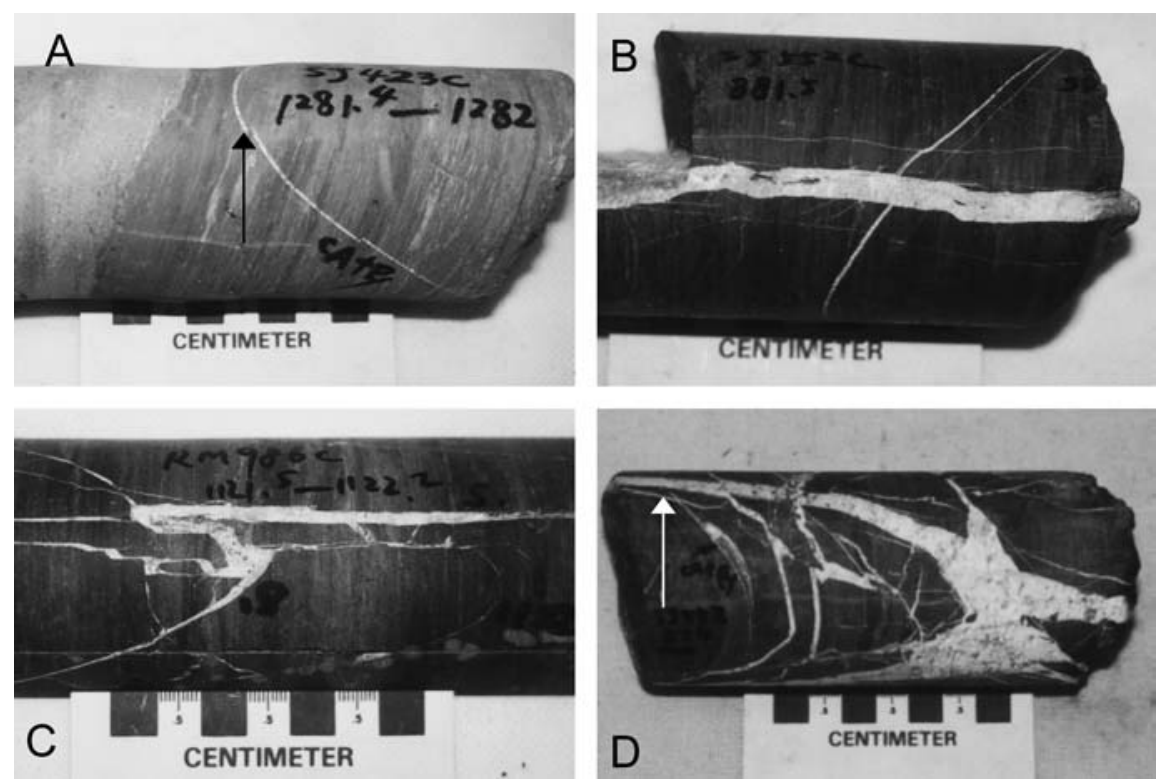

Fig. 6A-C Stereo plot showing contoured data for fractures through the entire wispy member in oriented drill hole RM986C. A All fractures; B fractures containing calcite; C fractures containing clay minerals with or without calcite
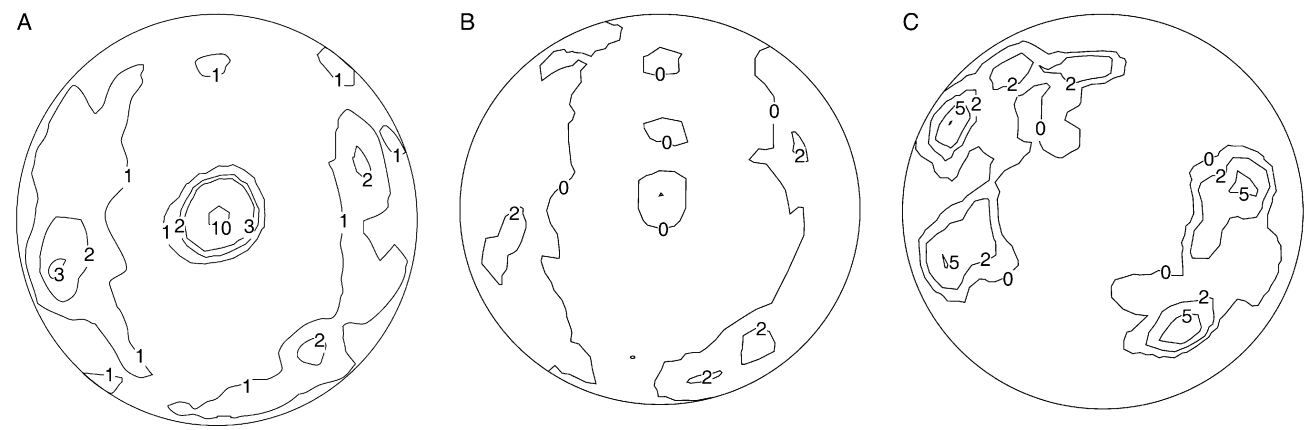

density and gold grade are not positively correlated in the four mineralized holes (Fig. 8), whether they are viewed as a group or individually (SJ552C, SJ435C, SJ443C, RM986C; Table 1). The hint of a negative correlation between fracture density and gold grade seen in most of the individual plots might be interpreted to indicate that gold was leached from high-grade rocks by later fracturing.

More detailed tests of the relation between fracture density and gold grade could be made by dividing fractures into groups based on their strike and dip. Strikes of fractures could be determined only in the oriented hole (RM986C). Measurements in this hole showed that fractures with strikes of 5-30, 50-60, and $150-180^{\circ}$ are most abundant, which is consistent with the prevailing northwesterly and northeasterly direction of faults in the area. None of these fracture groups shows a significant correlation with gold grade, indicating that the relation between gold grade and fracture density is not improved by classification of fractures according to strike (Table 2). Additional tests were made by dividing fractures in the unoriented and oriented holes into groups based on their dips, using arbitrary groupings of $0-20,21-40,41-60$, and $61-90^{\circ}$ (Table 1). Both positive and negative correlations were noted between gold grade and fracture density. A highly significant positive correlation was seen for fractures with dips of $41-60^{\circ}$ in SJ552C, and a somewhat less significant positive correlation was seen for fractures with the same dips in RM998C. Highly significant negative correlations between gold grade and fracture density were seen for fractures with dips of $61-90^{\circ}$ in RM986C and SJ552C and for fractures in the $0-20^{\circ}$ group for SJ443C.

Dips of fractures in all of these holes were not equally distributed, but rather are clustered in certain ranges. As a result, we carried out the same type of test focusing only on the range of dips that was most common for fractures in each hole. The most common fracture dips were in the $0-5^{\circ}$ range for holes SJ552C and SJ435C, in the $10-20^{\circ}$ range for $\mathrm{SJ} 443 \mathrm{C}$, and in the $5-15$ and $60-80^{\circ}$ ranges for RM998C. Correlations between gold grade and fractures that fall in these dip ranges are generally more significant than those observed for the arbitrary divisions used above. However, the only highly significant correlation is a negative one observed for the $5-15^{\circ}$ range in RM998C. We also carried out these tests using relative percent of fracture density for each hole, rather than absolute fracture density. The results of these tests (Table 1) are in general agreement with those using 

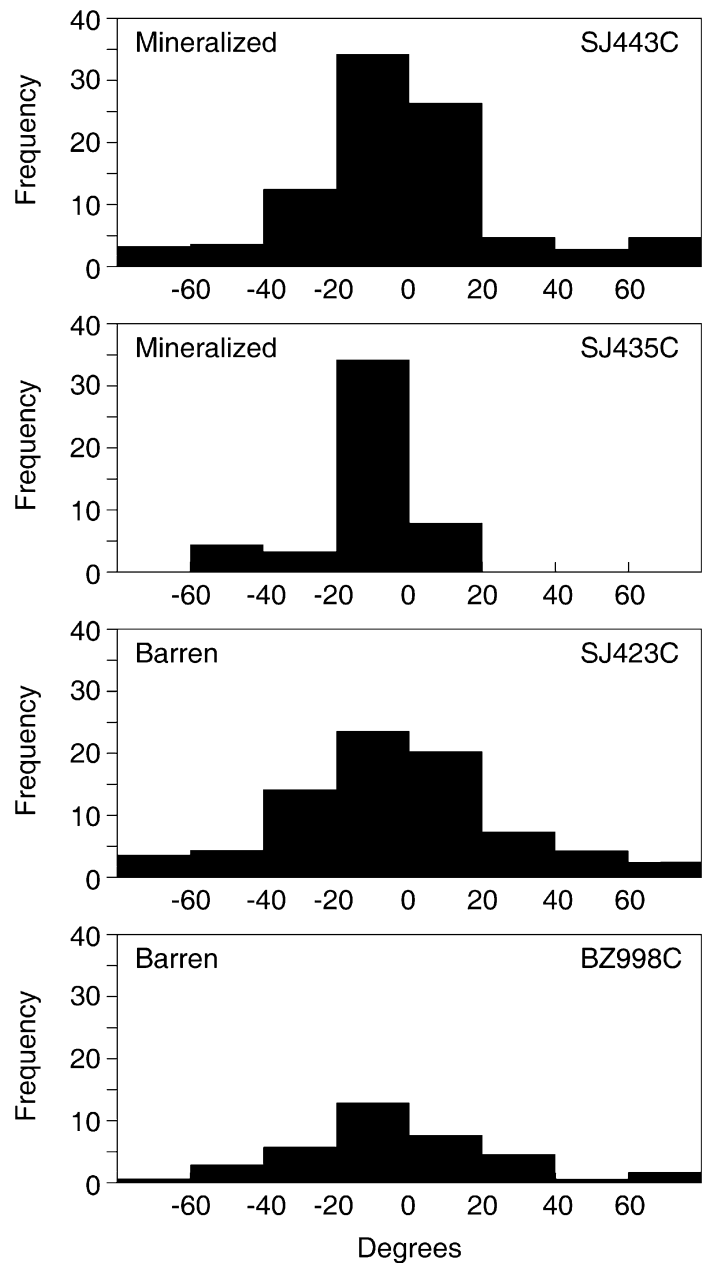

Fig. 7 Distribution of differences between dips (with respect to core axis) of cross cutting veins (young vein subtracted from old vein)

absolute fracture density, indicating significant positive correlations between gold grade and fracture density for fractures with dips in the $41-60^{\circ}$ range in RM998C and SJ552C, and significant negative correlations for fractures in the $61-90^{\circ}$ range for the same holes. It might be inferred from these relations that gold was introduced by fluids flowing along fractures with dips of $41-60^{\circ}$, but possibly removed by fluids flowing along fractures with dips of $61-90^{\circ}$, and that, more importantly, the appearance of a few vertical veins containing native gold in the Screamer zone is not an indication of large-scale structural control of primary mineralization.

Kaolinite alteration has been linked to gold mineralization in the Betze-Post system and calcite is most common outside areas of gold mineralization (Arehart et al. 1993; Emsbo et al. 1996; Ferdock et al. 1997). To test whether veins containing clay minerals or calcite are related to mineralization, we compared the distribution of gold grades in ore holes (RM986C, SJ435C, and SJ443C) with the distribution of the two classes of veins (other veins are not involved here because they are either not abundant or in almost horizontal fractures). In
RM986C and SJ443C, the proportion of calcite-filled fractures in core intervals with gold grades less than 0.1 opt is much larger than is the proportion of fractures containing clay minerals (Fig. 9). In contrast, in SJ435C, a slightly higher proportion of calcite veins has gold grades greater than 0.1 opt. Orientations of calcite veins and clay mineral ( \pm calcite) veins determined in RM986C also differ. Most calcite veins are nearly vertical and strike NNW or NE. Most kaolinite-bearing veins dip about 60 to $70^{\circ}$ and form two groups that strike NE. The orientation of these kaolinite-bearing veins coincides generally with the northeasterly strike and intermediate dip of fractures that were correlated most strongly with gold grades above, and appears to reflect the dominant northeast-trending faults in the district (Teal and Jackson 1997).

\section{Relation of gold grade to alteration}

To evaluate the relation of hydrothermal alteration to gold mineralization at Screamer, we determined degrees of silicification and decarbonatization in the hand samples by both megascopic and geochemical methods. In the megascopic approach, samples were classified into categories depending on ease of scratching (silicification) and degree of reaction with dilute acid $\mathrm{HCl}$ (decarbonatization) (Appendix).

Silicification shows a poor correlation to gold values. High and low grade samples are common in rocks with all degrees of silicification, as determined by scratching. Ease of scratching of sedimentary rocks, such as those at Screamer, could depend on both added silica (silicification) and the relative abundance of silicate clasts among the original sedimentary material. Kuehn and Rose (1992) noted that "excess $\mathrm{SiO}_{2}$ " calculated from major element chemical analyses is a good measure of silicification in Carlin-type deposits, and we used the data of the Appendix to calculate this parameter for our samples. If it is assumed that all aluminum is present in layered silicates (kaolinite, smectite, illite, or muscovite), excess $\mathrm{SiO}_{2}(\mathrm{wt} \%)=$ total $\mathrm{SiO}_{2}(\mathrm{wt} \%)-2 \times 60.09 \times \mathrm{Al}_{2} \mathrm{O}_{3}$ $(\mathrm{wt} \%) / 102$. Silica/alumina ratios vary in smectite and illite, but not enough to affect the calculation greatly. Calculated excess $\mathrm{SiO}_{2}$ values show a strong correlation with the four degrees of silicification determined by megascopic tests, suggesting that our megascopic tests were adequate to measure this parameter. Calculated excess $\mathrm{SiO}_{2}$ shows a poor correlation with gold values (Fig. 10), indicating a lack of direct relation between gold mineralization and silicification.

The relation between decarbonatization and gold is similarly ambiguous at Screamer. Most $(73 \%)$ of the wispy member samples containing no carbonate (class 0 , intense decarbonatization) contain more than $4 \mathrm{ppm}$ gold, and samples with moderate degrees of decarbonatization (classes 1 and 2) have smaller proportions of samples with more than $4 \mathrm{ppm}$ gold (57 and $35 \%$, respectively). However, fully $46 \%$ of the samples with no decarbonatization (class 3) contain more than $4 \mathrm{ppm}$ 
Fig. 8 Relation between total fracture density and gold grade for all mineralized holes, as well as individual mineralized holes (RM98-6C, SJ552C, SJ443C and $\mathrm{SJ} 435 \mathrm{C}$ ), and one barren hole (BZ998C)
Table 1 Correlation coefficients and significance level for plots of gold grade vs. total fracture density. Part I fracture density expressed as absolute value for fractures divided into groups based on (A) arbitrary divisions of dip angle and (B) most common dip angle. Part II fracture density (expressed as percent of total fracture density) for fractures divided into groups based on (A) arbitrary divisions of dip angle and (B) most common dip angle. First number in each entry is correlation coefficient and second number is significance level (percent). Highly significant correlations $(<99 \%)$ are shown in bold
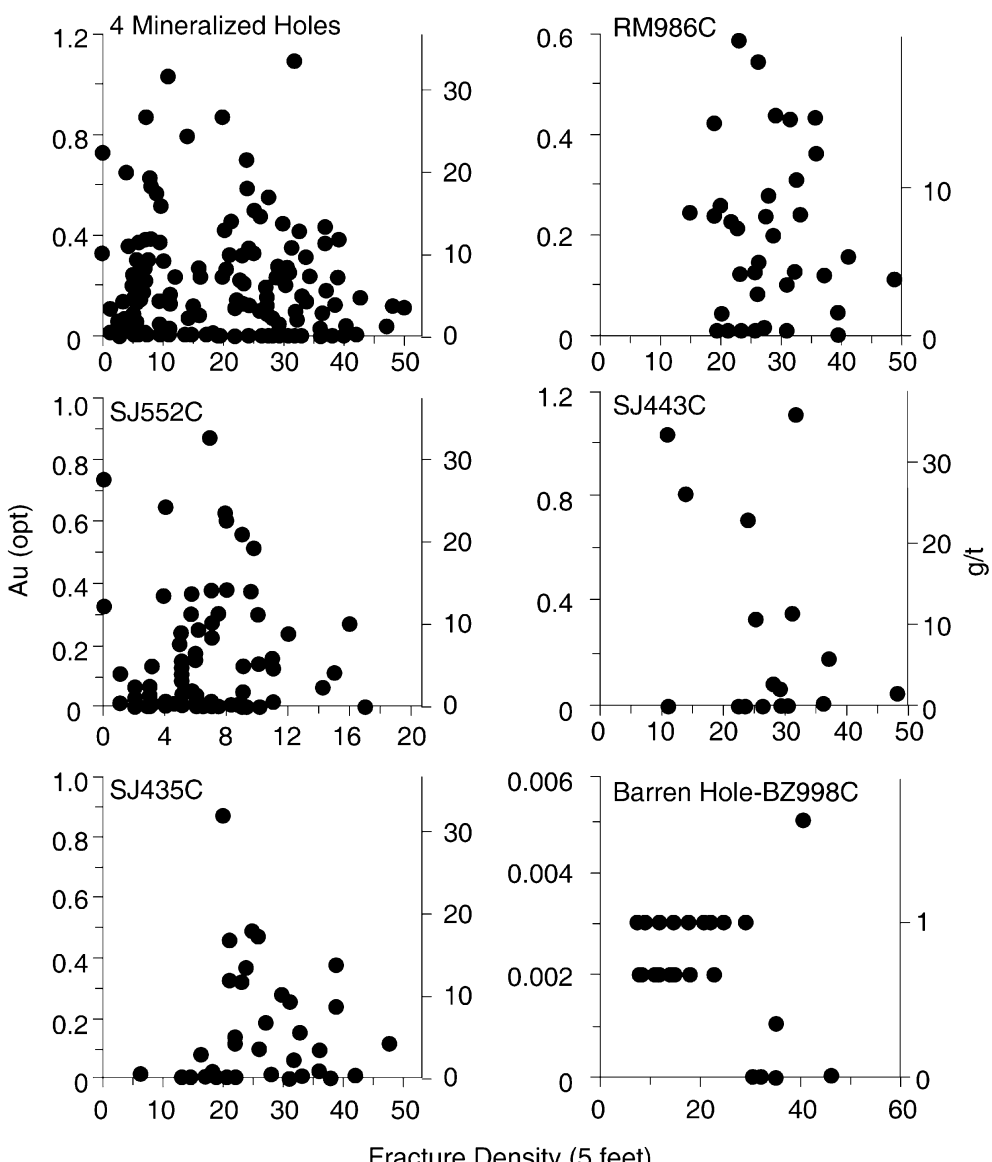

Part I. Fracture density expressed as absolute value

(A) Dip angle

$0-20^{\circ}$

$21-40^{\circ}$

RM986C

$-0.04(18.4)$

SJ552C

$-0.10(62.0)$

$0.12(51.8)$

SJ435C

$-0.48(99.8)$

$0.07(31.7)$

$41-60^{\circ}$

$60-80^{\circ}$

SJ443C

$0-5^{\circ}$

$-0.01(<10)$

$0.27(89.0)$

$0.33(99.9)$

$0.08(36.0)$

$-0.01(<10)$

$0.01(35.0)$

$-0.24(99.7)$

$-0.04(18.4)$

(B) Dip angle

$5-15^{\circ}$

RM986C

$-0.17(86.7)$

$-0.35(99.7)$

$10-20^{\circ}$

$-0.14(43.2)$

SJ552C

$0.17(69.0)$

$60-80^{\circ}$

0.07 (31.7)

SJ435C

SJ443C

$-0.31(81.0)$

Part II. Fracture density expressed as percentage of total fracture density

$\begin{array}{lcccc}\text { (A) Dip angle } & 0-20^{\circ} & 21-40^{\circ} & 41-60^{\circ} & 60-80^{\circ} \\ \text { RM986C } & -0.03(14.0) & 0.09(40.0) & \mathbf{0 . 3 7}(\mathbf{9 9 . 9 )} & \mathbf{- 0 . 4 0}(\mathbf{9 9 . 9 )} \\ \text { SJ552C } & 0.01(<10) & 0.00(0.00) & \mathbf{0 . 3 2}(\mathbf{9 9 . 9 )} & \mathbf{- 0 . 3 2}(\mathbf{9 9 . 9 )} \\ \text { SJ435C } & -0.02(08.0) & -0.04(18.4) & -0.08(36.0) & -0.02(08.0) \\ \text { SJ443C } & -0.33(82.7) & 0.14(43.2) & 0.31(81.0) & 0.07(22.3) \\ \text { (B) Dip angle } & 0-5^{\circ} & 5-15^{\circ} & 10-20^{\circ} & 60-80^{\circ} \\ \text { RM986C } & & -\mathbf{0 . 3 4}(\mathbf{9 9 . 9 )} & & 0.03(23.3) \\ \text { SJ552C } & -0.00(0.00) & & & \\ \text { SJ435C } & 0.10(44.1) & & -0.21(60.8) & \\ \text { SJ443C } & & & & \end{array}$

gold, indicating that not all samples with high gold grades underwent decarbonatization. Chemical analyses provide the same conclusion, showing that most samples with low $\mathrm{CO}_{2}$ contain high gold values, but samples with high $\mathrm{CO}_{2}$ have a wide range of gold values (Fig. 11).

Argillization is poorly developed at Screamer; strong and obvious clay alteration was observed only in sample
SJ443C-1128, which has a high gold grade $(53.8 \mathrm{ppm}$; Appendix). Reliable microscopic estimates of argillization could not be made for all samples in our suite because of fine grain size and uncertain genesis of most layered silicates, and further tests were based on chemical analyses in Appendix. Layered silicate minerals that might be present in the Screamer zone include illite, 
Table 2 Correlation coefficients for $(A)$ plots of total fracture density vs. gold grade in four mineralized drill holes; $(B)$ plots of fracture density vs. gold grade for fractures in oriented hole RM986C with fractures divided into groups based on most common strikes. First number is correlation coefficient and second number is significance level (percent)

\begin{tabular}{lllll}
\hline $\begin{array}{l}\text { (A) Drill } \\
\text { hole }\end{array}$ & SJ435C & SJ443C & SJ552C & RM986C \\
(B) Strike & $0.07(31.7)$ & $-0.29(76.0)$ & $-0.08(52.4)$ & \\
interval & $0.07(31.7)$ & $50-60^{\circ}$ & $150-180^{\circ}$ & $-0.06(27.5)$ \\
in RM986C & & & & \\
\hline
\end{tabular}
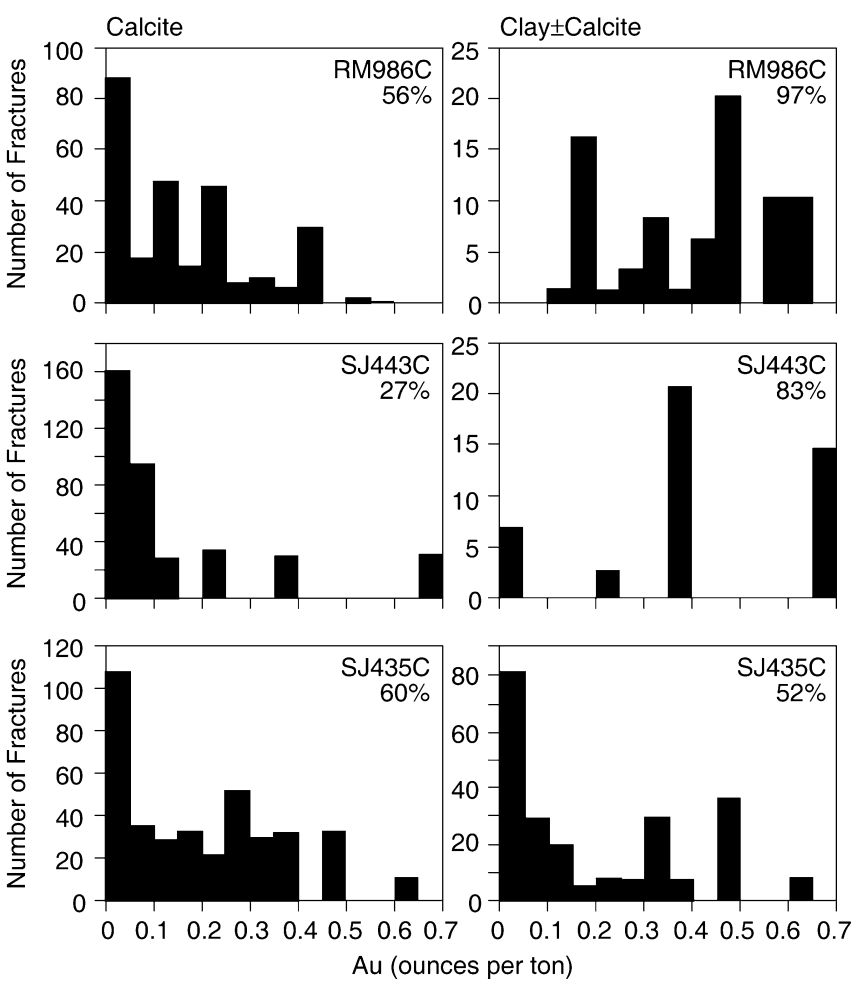

Fig. 9 Distribution of gold grades in veins containing calcite and those containing clay mineral with or without calcite for three drill holes. Percentage shown in diagrams is proportion of samples with grades greater than $0.1 \mathrm{opt} \mathrm{Au}$

sericite, and kaolinite, which have $\mathrm{K} / \mathrm{Al}$ (molar) ratios of $0,1: 3$, and 1:4.2, respectively. Smectite, which is also present in some deposits, has $\mathrm{K} / \mathrm{Al}$ ratios intermediate between kaolinite and sericite (Folger et al. 1998). Hydrothermal K-feldspar (molar K:Al ratio $=1: 1$ ) is associated with gold at Twin Creeks, but has not been seen at Screamer (Simon et al. 1999). These ratios can be used to obtain an approximate indication of the dominant layered silicate mineral present in these samples, keeping in mind that some layered silicates are detrital (Arehart et al. 1993) and mixtures of more than one of these minerals in a sample can yield intermediate ratios. Figure $12 \mathrm{~A}$ shows that $43 \%$ of the wispy member samples have molar $\mathrm{K} / \mathrm{Al}$ ratios less than those typical of illite, suggesting that these samples contain significant amounts of kaolinite and/or smectite. As can be seen in Fig. 13A there is a generally negative correlation

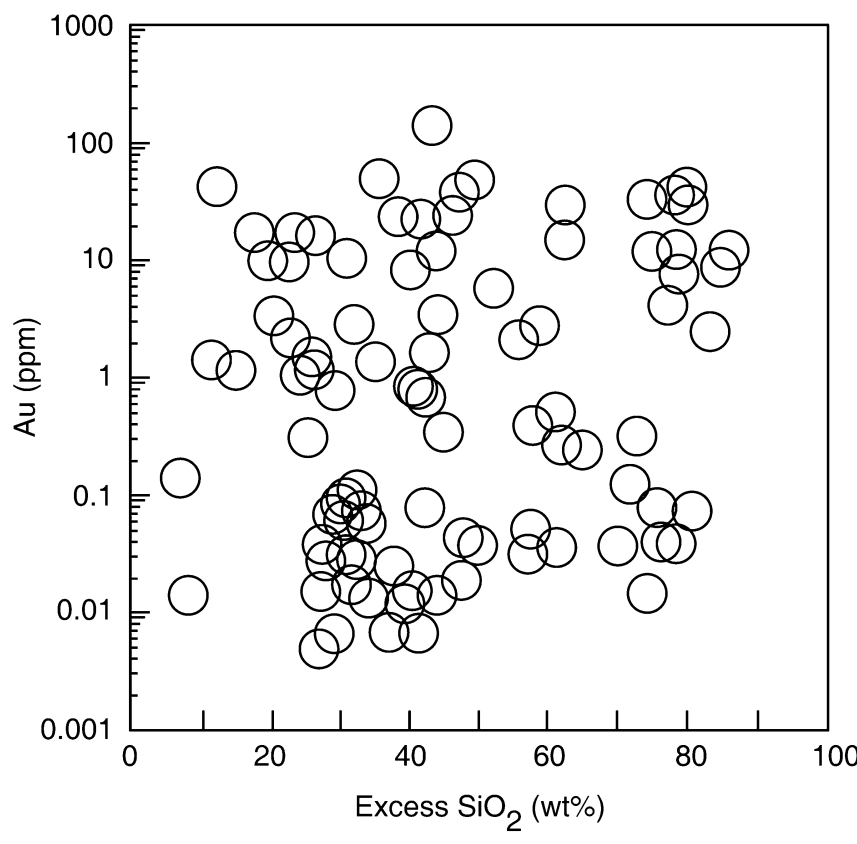

Fig. 10 Relation between excess $\mathrm{SiO}_{2}$ (calculated as explained in the text) and gold grade in core samples from the Appendix

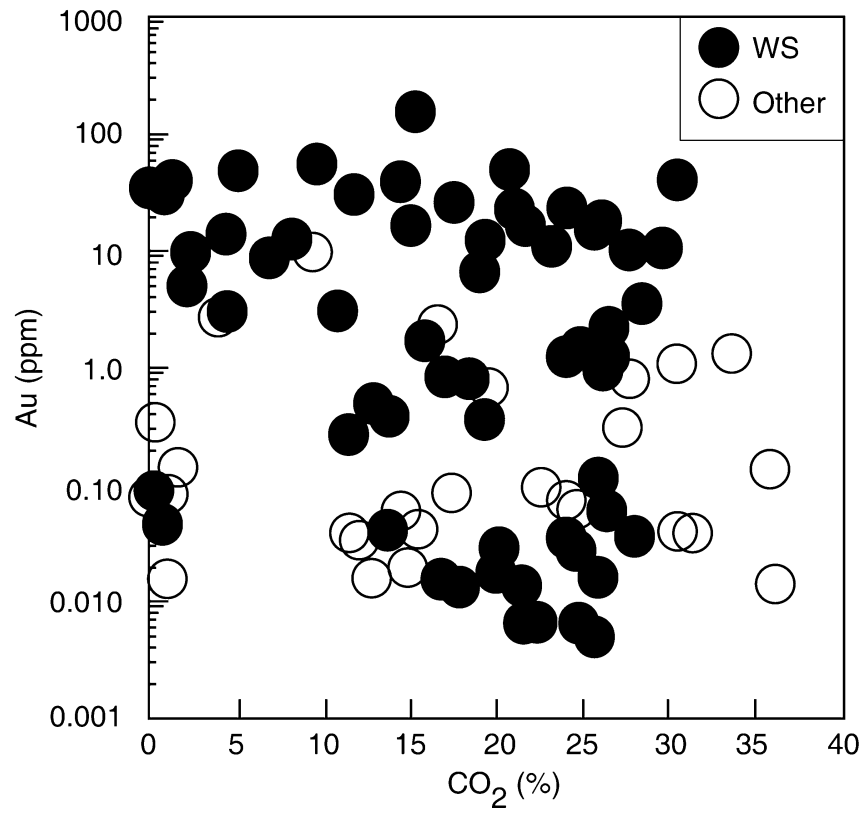

Fig. 11 Relation between $\mathrm{CO}_{2}$ and gold contents of all samples in the Appendix, including samples of wispy (WS) member. For reference, $\mathrm{CO}_{2}$ contents of calcite and dolomite are 44 and $47.7 \mathrm{wt} \%$, respectively

$\{R=-0.3, \quad n=58$, significance level (SL) $>99.9 \%$, between K/Al ratio and gold values for samples of the wispy member, as would be expected if argillization accompanied gold mineralization. This correlation is not significant for the planar member of the Popovich Formation $(R=-0.13, \mathrm{SL}<<99 \%$, Figs. 12B and 13B) and the Roberts Mountains Formation $(R=-0.24$, $\mathrm{SL}<99 \%$, Figs. 12B and 13C). Note that the diagrams 

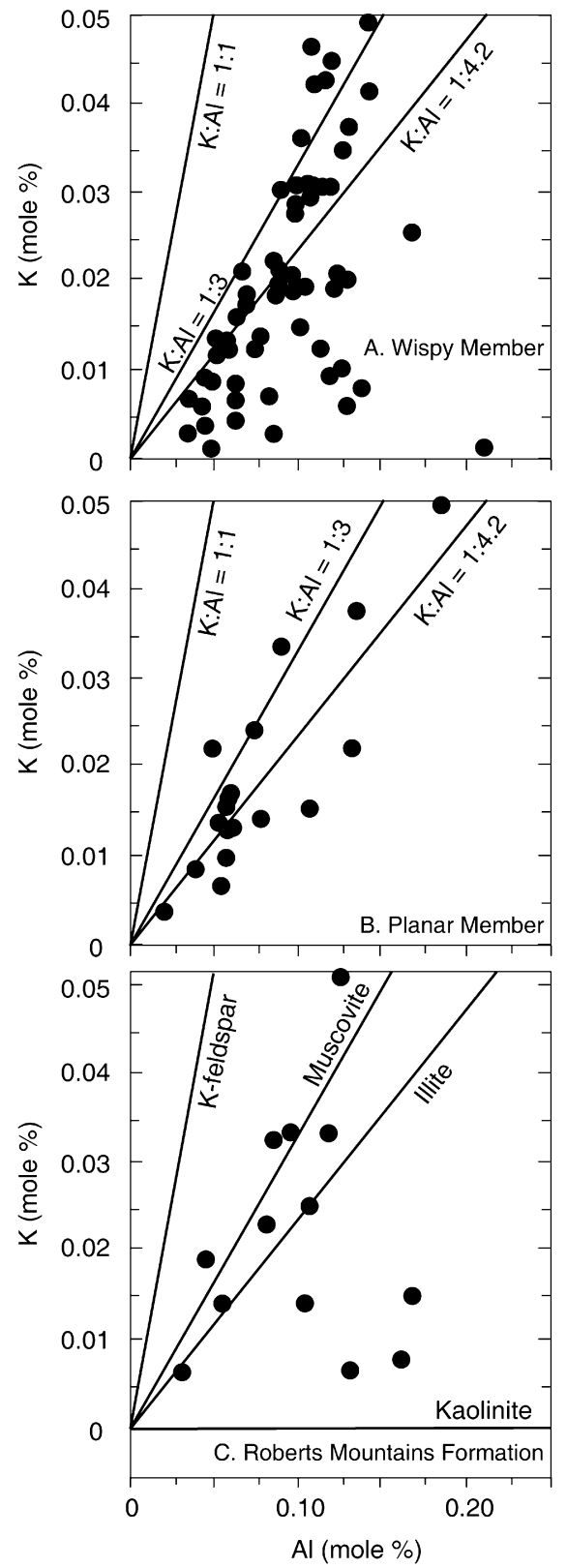

Fig. 12 Relation between $\mathrm{K}$ and $\mathrm{Al}$ contents of samples in the Appendix divided into the different stratigraphic units ( $W S$ wispy member; $P L$ planar member; $L L$ Roberts Mountains Formation). Lines show $\mathrm{K}: \mathrm{Al}$ atomic ratios for $\mathrm{K}$-feldspar (1:1), muscovite (1:3), illite (approximately 1:4.2), and kaolinite (horizontal axis). Ratio for smectite, which is not shown because of large range, would be between that of illite and kaolinite

show that some samples have $\mathrm{K}: \mathrm{Al}$ ratios intermediate between muscovite and $\mathrm{K}$-feldspar, possibly reflecting the presence of detrital grains of K-feldspar.

Pyrite is the most important feature related to gold grade at Screamer. Figure 14A, B shows the relation between iron, sulfur, and gold contents of the samples in the Appendix. Both ore and waste rock samples from within the general boundaries of the Screamer deposit fall along or slightly below a line defined by the Fe:S ratio of pyrite. In contrast, about half of the samples
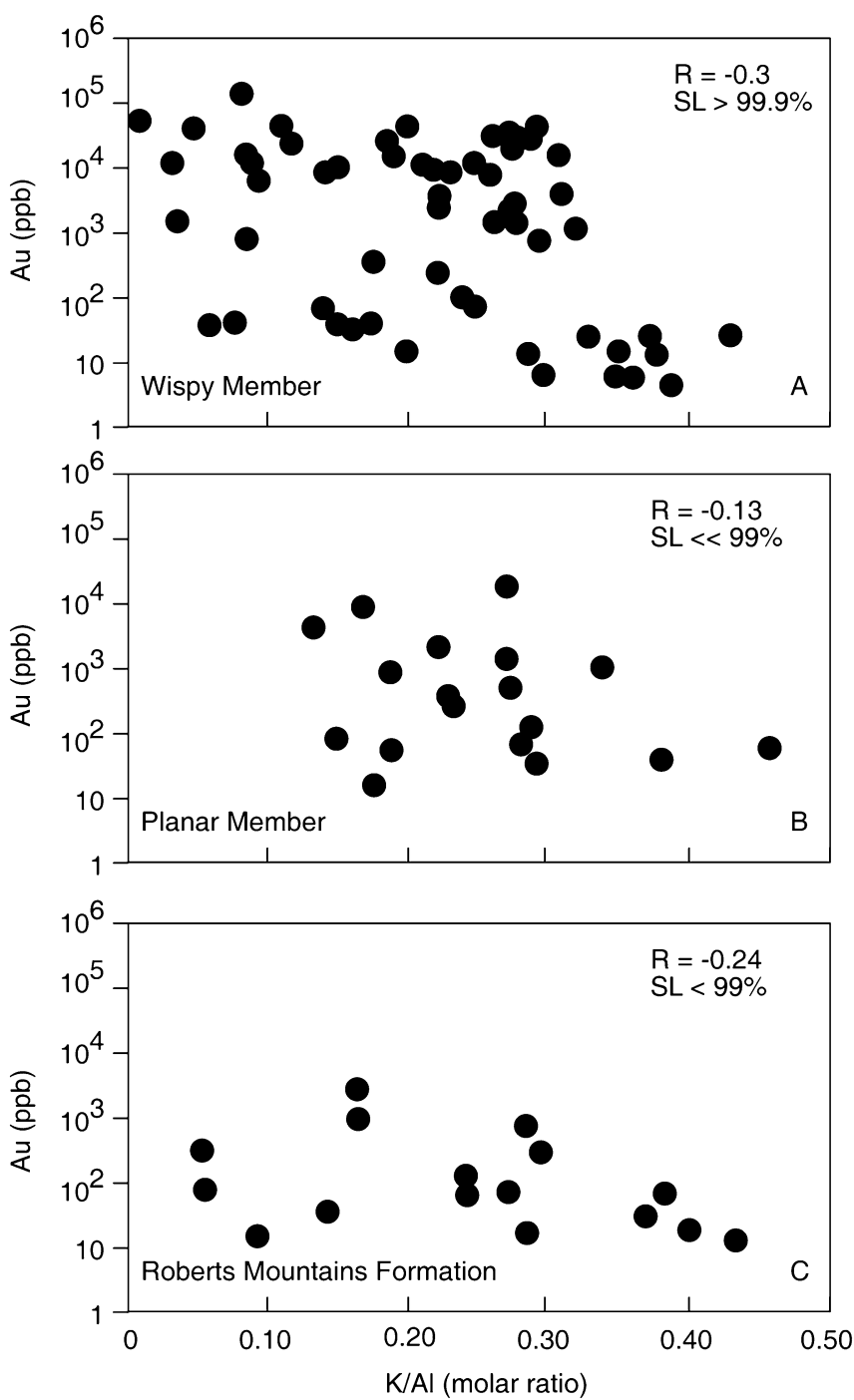

Fig. 13 Relation between $\mathrm{K} / \mathrm{Al}$ ratio and gold grade for hand specimens from the Appendix, divided according to host stratigraphic unit ( $W S$ wispy member; $P L$ planar member; $L L$ Roberts Mountains Formation)

from outside the Screamer zone, most of which have low gold grades, plot well below this line. This Fe:S relation is even stronger when it is plotted only for samples from the wispy member and it provides strong support for the presence of wide spread sulfidation of (i.e. addition of sulfur to) wall rocks in the Screamer zone. In addition to sulfidation, there is a strong relation between gold grades and abundance of pyrite. Pyrite content of samples was calculated from the data in the Appendix by determining the amount of sulfur required to host all arsenic in the sample in $\mathrm{As}_{2} \mathrm{~S}_{3}$, which serves as a proxy for arsenian pyrite, the main host for arsenic at Screamer, and deducting this amount from the total sulfide sulfur. Other sulfides, including stibnite, galena, sphalerite, and chalcopyrite, are scarce and were neglected in the calculation. The amount of pyrite was determined from the data of the Appendix using the relations: 

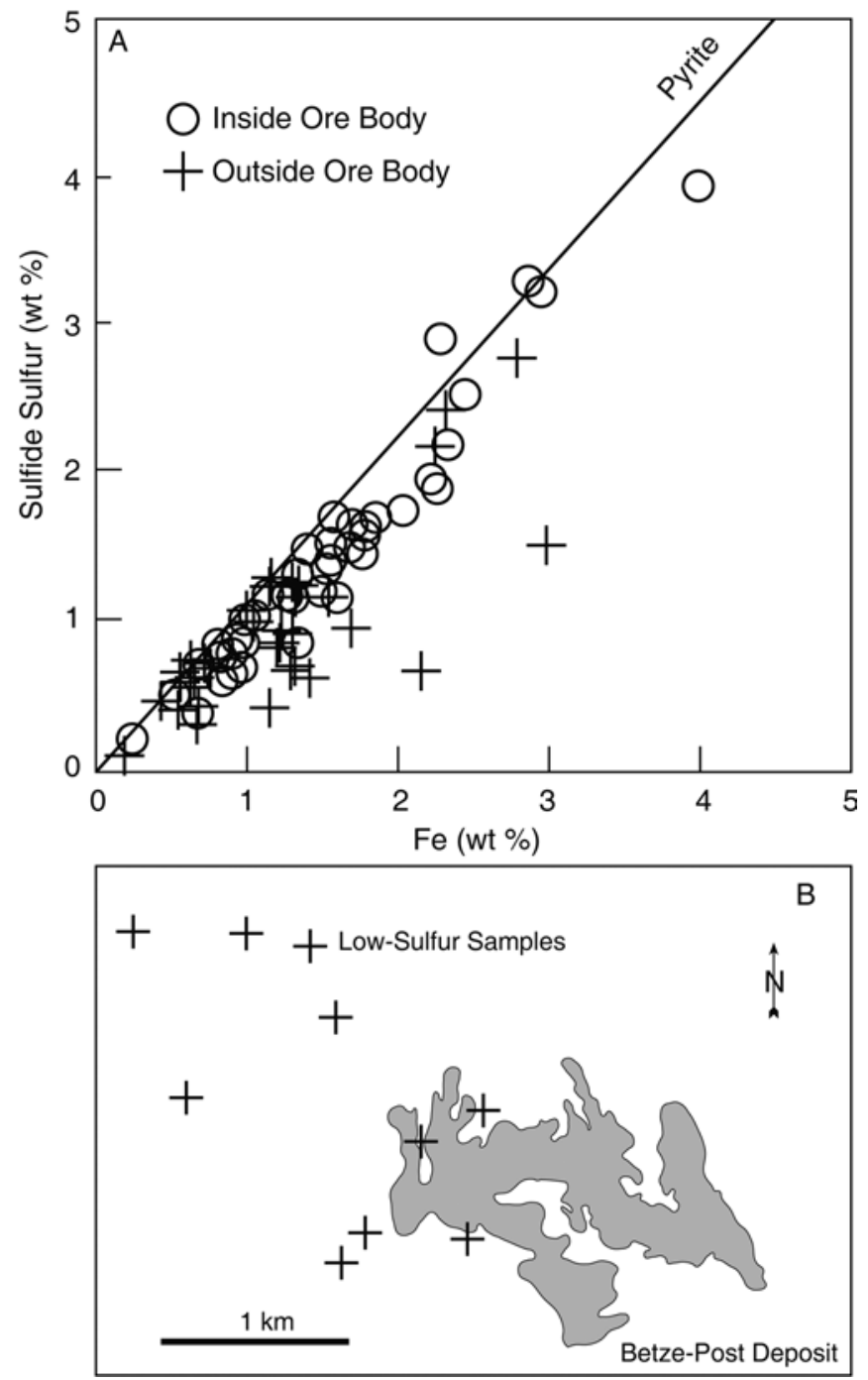

Fig. 14A, B Fe-S plot showing relative position of drill holes inside and outside the Screamer zone. Samples that plot above the pyrite line contain excess sulfur. Lower map shows location of holes that are outside the ore body

$\mathrm{S}_{\text {pyrite }}=\mathrm{S}_{\text {total }}-\left(1.5 * 32.06 * \mathrm{As}_{2} \mathrm{~S}_{3} \% / 74.92\right)$, and

$\mathrm{FeS}_{2}(\mathrm{wt} \%)=\mathrm{S}_{\text {pyrite }} *(54.85+64.12) / 64.12$.

The amount of pyrite determined in this way shows a strong positive correlation with gold content (Fig. 15). This indicates that the rock underwent both sulfidation and addition of pyrite during gold mineralization. The mineralogy, geochemistry, and isotope systematics of sulfidation and pyrite addition at Screamer are reviewed in more detail by Fortuna et al. (2003).

\section{Stability of ore and alteration assemblages and implications for gold depositing conditions}

Considerable uncertainty remains about the actual depositional conditions, particularly the depth, for

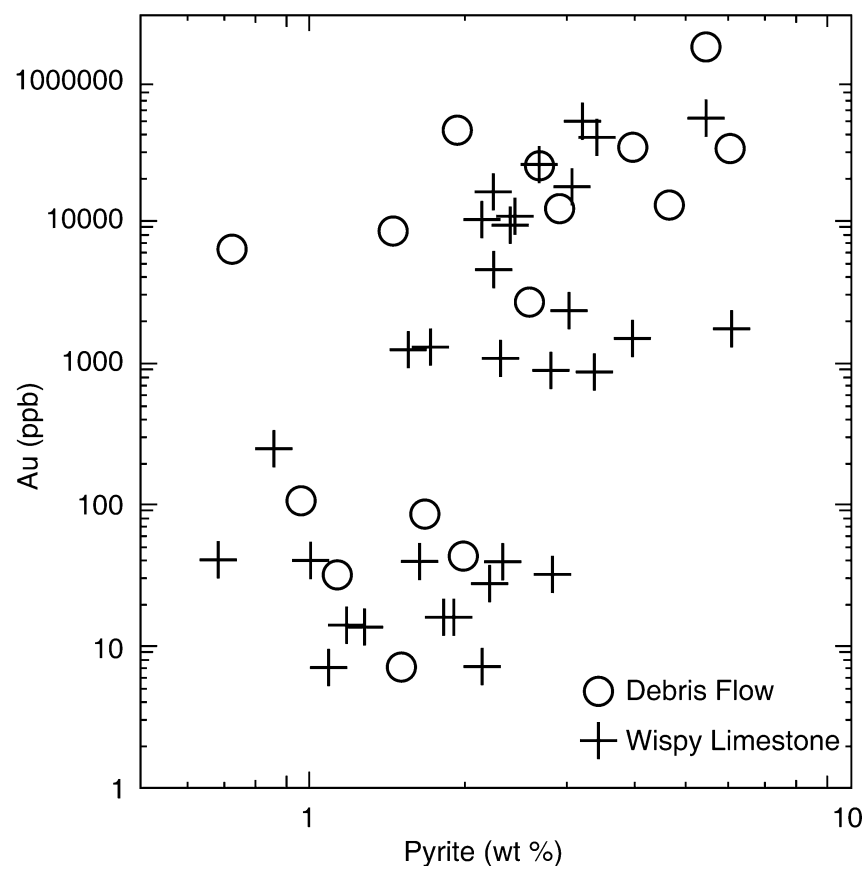

Fig. 15 Relation between gold grade and pyrite content calculated from whole-rock chemical analyses for samples in the wispy member divided according to lithology

Carlin-type mineralization (Hofstra and Cline 2000). Stability relations for ore and alteration assemblages can be used to place some constraints on these conditions. Alteration assemblages at Screamer include numerous examples of kaolinite and carbonate minerals that exhibit textures reflecting coexistence (Fig. 16AC). The form of the carbonate grains indicates that they were not dissolved during deposition of kaolinite and the calcite does not fill pores in decarbonated rock. We have interpreted these assemblages as primary and have used them in the calculations discussed below. Rutile is also present in the ore zone and sphene is absent.

The most common assemblages including carbonate minerals within the ore zone are rutile + (arsenian) pyrite + quartz \pm calcite \pm dolomite \pm pyrrhotite, rutile + quartz \pm calcite, quartz + calcite, and kaolinite + calcite + dolomite + quartz \pm muscovite or illite. The main wall rock assemblages are: pyrite + quartz + dolomite + calcite \pm rutile and dolomite + quartz + calcite \pm illite or muscovite. Reactions that involve these assemblages and limit the amount of $\mathrm{CO}_{2}$ or $\mathrm{H}_{2} \mathrm{O}$ in the mineralizing fluid include:

1. Kaolinite +2 calcite + quartz

$$
=\text { prehnite }+2 \mathrm{CO}_{2}+\mathrm{H}_{2} \mathrm{O}
$$

2. Kaolinite + calcite +2 quartz $+2 \mathrm{H}_{2} \mathrm{O}$

$$
=\text { laumontite }+\mathrm{CO}_{2}
$$

3. 3 Kaolinite +4 calcite

$$
=2 \text { clinozoisite }+4 \mathrm{CO}_{2}+5 \mathrm{H}_{2} \mathrm{O}
$$

4. Kaolinite +2 quartz $=$ pyrophyllite $+\mathrm{H}_{2} \mathrm{O}$

5. 5 Dolomite +8 quartz $+\mathrm{H}_{2} \mathrm{O}$

$$
=\text { tremolite }+3 \text { calcite }+7 \mathrm{CO}_{2}
$$



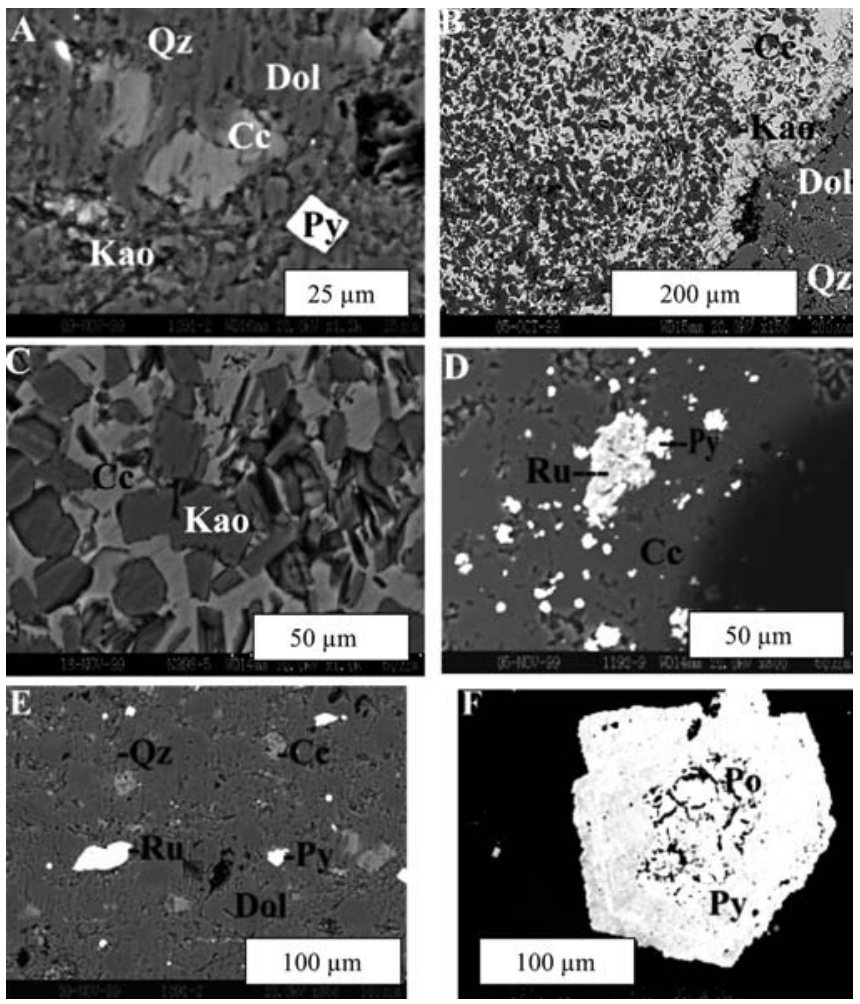

Fig. 16A-F SEM images of mineral assemblages in and around the Screamer zone. A Ore-stage dolomite (dominant) + calcite + kaolinite (minor) in wall rock (CD18C-1091); B ore-stage calcite + kaolinite + quartz + dolomite (minor) in ore zone (SJ435C-998); $\mathbf{C}$ enlarged image of ore-stage kaolinite + calcite in $\mathbf{D}$; $\mathbf{D}$ closely associated pyrite + rutile in ore zone (BZ960C-1192); E separate grains of diagenetic(?) pyrite + rutile in barren wall rock (CD18C1091); F diagenetic(?) pyrrhotite core and arsenian pyrite rim (BZ976C-1222)

\section{5 Dolomite + kaolinite + quartz $+2 \mathrm{H}_{2} \mathrm{O}$ \\ $=$ clinochlore +5 calcite $+5 \mathrm{CO}_{2}$}

7. Rutile + quartz + calcite $=$ sphene $+\mathrm{CO}_{2}$

The $\mathrm{T}-X$ relations for these reactions will depend, in part, on the salinity of the aqueous fluid, which is low for Carlin-type deposits in general (Hofstra and Cline 2000, their Table 5), although no direct observations were made on samples from the Screamer zone.

Fluid inclusion data summarized by Hofstra and Cline (2000, their Fig. 21) indicate that temperatures for Carlin-type systems ranged from 120 to $220{ }^{\circ} \mathrm{C}$ with a few as high as $300{ }^{\circ} \mathrm{C}$ and that pressures were between 330 and 650 bar. Additional constraints on temperature of formation of these deposits can be obtained from pyrrhotite-pyrite relations. Pyrrhotite, which forms a central core for overgrowth arsenian pyrite in one sample at Screamer (Fig. 16F) is magnetic and, therefore, monoclinic (Vaughan and Craig 1997). Kissin and Scott (1982) identified an upper stability limit of $254{ }^{\circ} \mathrm{C}$ for monoclinic pyrrhotite for pressures of 61-890 bar, which agrees with the estimates from fluid inclusions noted above. According to phase relations determined by Kissin and Scott (1982), monoclinic pyrrhotite with
$46.2 \mathrm{~mol} \% \mathrm{Fe}$ coexists with pyrite at an approximate temperature of $100-150{ }^{\circ} \mathrm{C}$. The effect of the minor arsenic $(0.2 \mathrm{wt} \%$ As in pyrite and pyrrhotite) on the stability of pyrrhotite and pyrite is not known, but is likely to be small. Because pyrrhotite is almost never seen in these systems (the pyrrhotite core shown in Fig. 16 is probably pre-mineralization in age), temperatures probably did not fall below this range $\left(100-150{ }^{\circ} \mathrm{C}\right)$, which agrees with the estimate made above.

Figure 17A shows temperature-composition $(\mathrm{T}-X)$ phase relations for the alteration reactions listed above at pressures of 500 bar, which is near the upper end of conditions thought to be typical of Carlin-type mineralization. Clinochlore, clinozoisite, laumontite, pyrophyllite, and prehnite are not present at Screamer. Thus, the mineralizing fluid was in equilibrium with the assemblage below the line for each reaction. According to these relations, reaction (6) (dolomite + kaolinite + quartz $+\mathrm{H}_{2} \mathrm{O}=$ clinochlore + calcite $+\mathrm{CO}_{2}$ ) provides the most important upper limit on temperatures of Carlin-type mineralization. Further limits can be placed on mineralizing conditions by reference to the $\mathrm{H}_{2} \mathrm{O}-\mathrm{CO}_{2}$ solvus, which is also plotted in Fig. 17A. Fluids above or to the left of this solvus are single phase and those below or to the right of it consist of immiscible $\mathrm{H}_{2} \mathrm{O}$-rich and $\mathrm{CO}_{2}$-rich fluids. Mineralizing fluids in Carlin-type deposits are thought to have been largely single-phase (e.g., no boiling; Hofstra and Cline 2000), indicating that the fluid plots above and/or to the left of the $\mathrm{H}_{2} \mathrm{O}-\mathrm{CO}_{2}$ solvus. As can be seen in Fig. 17A, for 500 bar this limits temperatures to less than about $200{ }^{\circ} \mathrm{C}$ and $X \mathrm{CO}_{2}$ to less than $4 \mathrm{~mol} \%$ (i.e., the volume between curve 6 and the $\mathrm{H}_{2} \mathrm{O}-\mathrm{CO}_{2}$ solvus). These limits are in good agreement with independent estimates of maximum $\mathrm{XCO}_{2}$ of 2 to $4 \mathrm{~mol} \%$ based on fluid inclusion gas analyses (Graney et al. 1991; Hofstra and Cline 2000).

Conversion of pressures to depths requires a decision about the degree to which hydrostatic conditions might have prevailed in Carlin-type systems. In view of the extremely porous nature of most altered rock in these deposits and the large faults that cut the systems, conditions were probably at or near hydrostatic. Thus, pressures of 500 bar would require depths of about $5 \mathrm{~km}$. Calculation of relations for reaction 6 at pressures of 300 and 100 bar in Fig. 17B provide insights into possible upper limits for Carlin-type mineralization (i.e., minimum depths for mineralization). Pressures of 300 bar representing depths of $3 \mathrm{~km}$ under hydrostatic conditions would allow mineralizing fluids with maximum temperatures of $175^{\circ} \mathrm{C}$ and $X \mathrm{CO}_{2}$ of $3 \mathrm{~mol} \%$, which are not greatly different from conditions indicated for 500 bar. Pressures of 100 bar representing hydrostatic depths of $1 \mathrm{~km}$, however, would limit the mineralizing fluid to unrealistically low temperatures of about $100{ }^{\circ} \mathrm{C}$ and very low $\mathrm{CO}_{2}$ contents. Thus, geologic relations and phase equilibria suggest that Carlin-type mineralization probably formed at pressures of at least 300 bar, which limits depths to at least $3 \mathrm{~km}$ under hydrostatic conditions. If conditions approached 

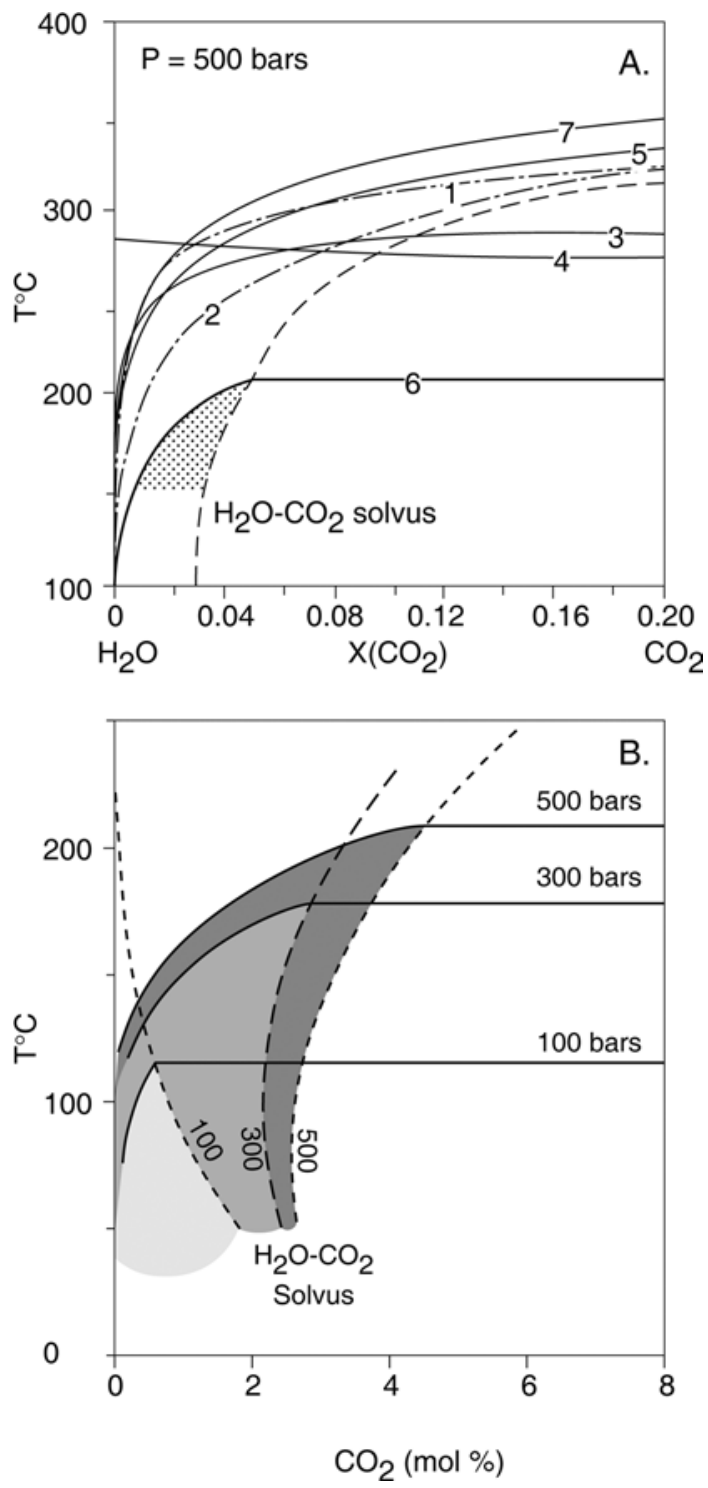

Fig. 17 A $\mathrm{T}-\mathrm{XCO}_{2}$ diagram for reactions 1 kaolinite +2 calcite + quartz $=$ prehnite $+2 \mathrm{CO}_{2}+\mathrm{H}_{2} \mathrm{O} ; 2$ laumontite $+\mathrm{CO}_{2}=$ kaolinite + calcite +2 quartz $+2 \mathrm{H}_{2} \mathrm{O} ; 33$ kaolinite +4 calcite $=2$ clinozoisite $+4 \mathrm{CO}_{2}+5 \mathrm{H}_{2} \mathrm{O} ; 4$ kaolinite +2 quartz $=$ pyrophyllite $+\mathrm{H}_{2} \mathrm{O} ; 55$ dolomite +8 quartz $+\mathrm{H}_{2} \mathrm{O}=$ tremolite +3 calcite $+7 \mathrm{CO}_{2} ; 65$ dolomite + kaolinite + quartz $+2 \mathrm{H}_{2} \mathrm{O}$ $=$ clinochlore +5 calcite $+5 \mathrm{CO}_{2} ; 7$ rutile + quartz + calcite $=$ sphene $+\mathrm{CO}_{2}$, at 500 bar. For each reaction, phases on the righthand side fall above the line. $\mathrm{H}_{2} \mathrm{O}-\mathrm{CO}_{2}$ solvus is from Takenouchi and Kennedy (1964) and thermodynamic calculations were carried out with the program of Holland and Powell (1998) assuming that fluid pressure equaled total pressure, whether total pressure was hydrostatic or lithostatic. Dashed lines (1) and (2) involve laumontite and prehnite, which decompose above 210 and $370{ }^{\circ} \mathrm{C}$, respectively. Assemblages typical of Carlin-type mineralization are stable in the area indicated below the mineral reaction lines and to the left of/above the $\mathrm{H}_{2} \mathrm{O}-\mathrm{CO}_{2}$ solvus. B Phase relations for reaction 6 and the $\mathrm{H}_{2} \mathrm{O}-\mathrm{CO}_{2}$ solvus at pressures of 100, 300, and 500 bar. Assemblages typical of Carlin-type mineralization are stable in the area indicated below the mineral reaction lines and to the left of/above the $\mathrm{H}_{2} \mathrm{O}-\mathrm{CO}_{2}$ solvus boundaries, and limit Carlin-type mineralization to pressures of more than 300 bar, which correspond to depths of about $3 \mathrm{~km}$ under hydrostatic conditions lithostatic, which seems less likely, depths of 1 to $2 \mathrm{~km}$ might have been possible.

Further estimates of the composition of the mineralizing fluid can be based on reactions involving sulfide, sulfate, oxide, and carbonate minerals in the ore assemblage. Rutile closely associated with pyrite is widespread in Screamer ore and probably resulted from sulfidation of ilmenite (Fig. 16D, E); pyrrhotite cores are overgrown by pyrite in a few locations (Fig. 16F). Stabilities of these phases are determined by reactions including:

8. Ilmenite $+\mathrm{S}_{2}=$ pyrite + rutile $+1 / 2 \mathrm{O}_{2}$

9. Ilmenite $+1 / 2 \mathrm{~S}_{2}=$ pyrrhotite + rutile $+1 / 2 \mathrm{O}_{2}$

10. Pyrrhotite $+1 / 2 S_{2}=$ pyrite

11. Anhydrite $+\mathrm{CO}_{2}=$ calcite $+1 / 2 \mathrm{~S}_{2}+3 / 2 \mathrm{O}_{2}$

How well these reactions constrain actual fluid compositions will depend on reaction rates at these low temperatures. The widespread occurrence of rutile formed from sulfidation of ilmenite in Carlin settings indicates that the first two reactions probably went to completion. Of the remaining two reactions, anhydritecalcite equilibria is most likely to proceed because dissolved calcium is abundant in Carlin-type mineralizing systems. Figure 18 shows $f_{\mathrm{O} 2}-f_{\mathrm{S} 2}$ relations for these phases. In these calculations, the activity of $\mathrm{FeS}$ in pyrite was set at 0.45 (Vaughan and Craig 1997) and $\mathrm{CO}_{2}$ was regarded as an ideal gas with a fugacity coefficient of one. The partial molar volume of $\mathrm{CO}_{2}$ in water is about $35 \mathrm{~cm}^{3}$ and does not change much (about $32-37 \mathrm{~cm}^{3} /$ mol) at temperatures less than $250^{\circ} \mathrm{C}$ and pressures less than 1,000 bar (Malinin 1974). The anhydrite-calcite boundary will move only a few tenths of a $\log$ unit in $\mathrm{O}_{2}$ or $S_{2}$ space even if fugacity coefficients are included. For instance, the data from Spycher and Reed (1988) can be used to obtain approximate fugacity coefficients for $\mathrm{CO}_{2}$ of 0.5 and 0.75 at 1,000 bar and 150 and $210{ }^{\circ} \mathrm{C}$, respectively. These coefficients move the anhydrite-calcite line only 0.3 or $0.1 \log$ units, respectively, in Fig. 18. These considerations mean that phase relations shown here would be nearly identical at 500 bar. No attempt has been made to consider the relations involving arsenian pyrite, a phase that is likely to be metastable relative to pyrite and an arsenic-bearing phase.

The widespread occurrence of pyrite and calcite, and extreme scarcity of pyrrhotite and anhydrite in the ore zone indicate that the mineralizing fluid had compositions within the hatched field in Fig. 18. This range of conditions can be constrained further by stabilities of barium and arsenic-bearing phases. Witherite, which is absent from Carlin-type ores, is stable over most of the stippled field. The assemblage barite-calcite, which is common locally in Carlin-type ores, is stable over a relatively small range of $f_{\mathrm{O} 2}$ in the upper part of the hatched field (stippled area; Fig. 18). The $f_{\mathrm{S} 2}$ conditions within this smaller field can be constrained further by the mineralogy of arsenic-bearing phases. The presence of stoichiometrically pure arsenopyrite also limits condi- 


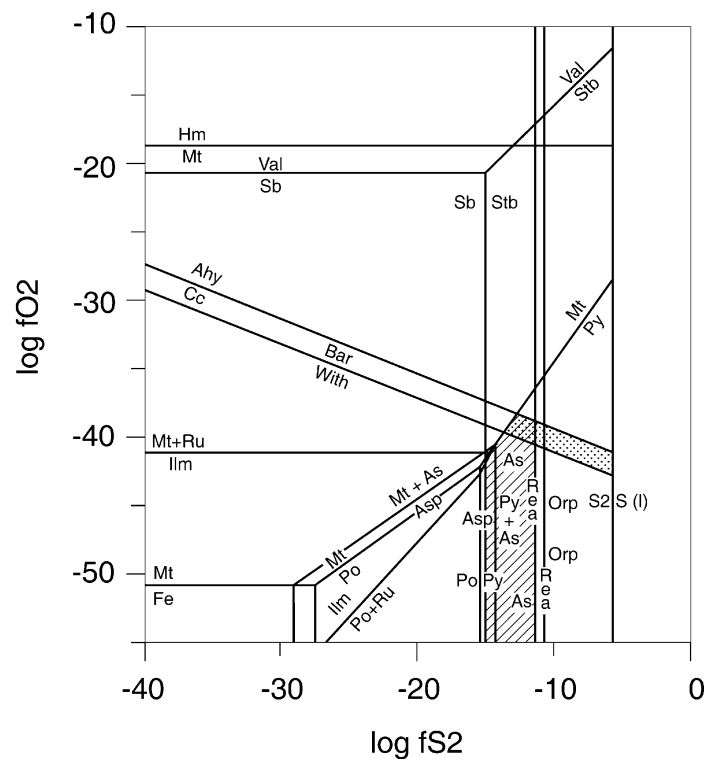

Fig. 18 Diagram of $\log _{10} f_{\mathrm{O} 2}$ vs. $\log _{10} f_{\mathrm{S} 2}$ at $1 \mathrm{kbar}, 210{ }^{\circ} \mathrm{C}$, and $X \mathrm{CO}_{2}=0.02$ for reactions in the systems $\mathrm{Fe}-\mathrm{Ti}-\mathrm{As}-\mathrm{S}-\mathrm{O}, \mathrm{Ba}-\mathrm{S}-\mathrm{C}-$ $\mathrm{O}, \mathrm{Ca}-\mathrm{S}-\mathrm{C}-\mathrm{O}$ and $\mathrm{Sb}-\mathrm{S}-\mathrm{O}$. Dotted field marks stability of calcitebarite-pyrite assemblage and cross hatched field shows stability of field for pyrite-calcite with either arsenopyrite or arsenic. A stability field for the presumably metastable arsenian pyrite (AsPy) is not shown. The upper limit of its metastability field (S2 + As-Py $=>$ As + Py) will fall to the left of the Asp $=$ As + Py boundary. In the Asp field, arsenian pyrite should react to form arsenopyrite and pyrite via the solid-solid reaction As-Py $=>$ Py + Asp. It could form and be preserved if arsenopyrite fails to nucleate and grow. Anh Anhydrite; Asp arsenopyrite; Bar barite; $\mathrm{Cc}$ calcite; $\mathrm{Hm}$ hematite; Ilm ilmenite; $M t$ magnetite; Orp orpiment; $P o$ pyrrhotite; $P y$ pyrite; Rea realgar; $R u$ rutile; $S t b$ stibnite; Val valentinite; Wth witherite. Sources of data: Barton (1969), Barin (1995), Robie and Hemingway (1995)

tions to a narrow field just beside the pyrrhotite-pyrite line, and the presence of arsenic expands this field to include the cross hatched zone in Fig. 18. The presence of either realgar or orpiment would indicate higher $f_{\mathrm{S} 2}$ conditions. Paragenetically early arsenopyrite is found in the Betze part of the Betze-Post system, whereas paragenetically later realgar and orpiment are found throughout the system (Ferdock et al. 1997). Thus, $f_{\mathrm{S} 2}$ conditions were moderate at the start of mineralization and continued to rise throughout the process to very high values by the end of mineralization.

\section{Controls, conditions, and timing of gold mineralization at Screamer}

Gold mineralization at Screamer shows surprisingly ambiguous relations to lithologic, structural, and alteration features that have been linked to gold in other Carlin-type deposits. Gold grades in the wispy member of the Popovich Formation, the main ore host at Screamer, are slightly higher in rock units that contain a large proportion of debris flow material, but this relation does not account for most ore. Attempts to correlate gold grades with fracture density were also generally unsuccessful, although gold grades do appear to correlate with kaolinite-bearing fractures, particularly those with northeasterly trends. Finally, gold grade correlates poorly with silicification and decarbonatization, and although some gold does appear to be associated with rock containing kaolinite, much is not. The only rock features that relate directly to gold mineralization are sulfidation and addition of pyrite. Nearly all wispy member rocks that are inside the Screamer zone have been completely sulfidized regardless of whether they contain gold or not, and there is a strong correlation between gold and pyrite contents of the ore. In contrast, many parts of the wispy member outside the Screamer zone have undergone only partial sulfidation and lack abundant pyrite.

These observations indicate that the key reaction in formation of Screamer ore was deposition of arsenian pyrite. Although some of this pyrite was deposited in response to sulfidation of iron already in the rock, much of it consists of iron and sulfur (and arsenic) that were added to the rock. In view of the absence of good evidence for other types of rock alteration, it is unlikely that deposition of pyrite was triggered by rockwater interaction. Instead, it might have been caused by cooling, oxidation of a fluid containing dissolved iron and sulfur, or mixing of an invading sulfidebearing ore fluid with a resident fluid containing iron. In areas lacking extensive structural deformation, fluid mixing of this type would be controlled by lithologic features, especially porosity, and would produce a stratiform zone of mineralization similar to that seen at Screamer. Estimates of mineralizing conditions at Screamer using mineral stabilities indicate a lower limit of about 300 bar for mineralization, which requires depths of at least $3 \mathrm{~km}$ under hydrostatic conditions. Sulfidation state of the mineralizing fluid began at relatively high values and increased throughout mineralization.

These observations also provide hints about the relation between the hydrothermal history of the BetzePost deposit and the complex geologic evolution of the Carlin region. The most important early events in the history of the deposit were sulfidation of the wispy member and formation of flat fractures, which probably took place under lithostatic conditions. The scarcity of pyrite in flat fractures, suggests that sulfidation came first, possibly as a diagenetic event. Near lithostatic pressures, which were required to form the flat fractures, probably prevailed during Late Paleozoic or Early Mesozoic time, when cover over the Screamer zone was thickest. The most important late events are pyritization of the Screamer zone and formation of northeast-trending, kaolinite-filled fractures that formed under hydrostatic pressure conditions. These fractures probably correlate with northeast-trending faults of possible Oligocene to Eocene age that are widespread in the Carlin Trend and have been suggested to be important controls on mineralization (Teal 
and Jackson 1997; Theodore et al. 1998; Tosdal and Nutt 1999).

Acknowledgements This project was supported by Barrick Goldstrike Mining Corporation and the National Science Foundation (EAR 9804963), to both of which we are very grateful. Barrick management and geologists, including K. Bettles, E. Lauha, G. Griffin, J. Lamb, and J. Zimmerman were generous with help of all kinds while we were on the property. Francois Robert of Barrick gave special assistance on the structural measurements, John Fortuna discussed aspects of his work on sulfidation, and Dan Core carried out some mineral stability calculations and discussed pressure constraints with us. Al Hofstra and Peter Vikre provided very helpful reviews of an earlier version of this manuscript.

\section{Appendix}

Chemical analyses and calculated features of samples from the Screamer zone of the Betze-Post deposit

WS Wispy limestone; $P L$ planar limestone; $L L$ Roberts Mountains Formation; $H B$ hydrothermal breccias; $S B$ sedimentary breccias; $D F$ debris flow; $C B$ collapse breccias; $T B$ tectonic breccias; $H F$ hornfels; $K B$ crackle breccias; $F H$ fossil hash; unalt. unaltered; deca. decarbonation; $\mathrm{ExSiO}_{2}$ excess $\mathrm{SiO}_{2} ; \mathrm{Py}$ pyrite

\begin{tabular}{|c|c|c|c|c|c|c|c|c|c|c|c|c|c|c|c|}
\hline \multirow[b]{3}{*}{ Drillhole } & \multirow[b]{3}{*}{$\begin{array}{l}\text { Hole } \\
\text { No }\end{array}$} & \multirow[b]{3}{*}{$\begin{array}{l}\text { Depth } \\
\text { (ft) }\end{array}$} & \multirow[b]{3}{*}{$\begin{array}{l}\text { Struc- } \\
\text { ture }\end{array}$} & \multirow[b]{3}{*}{$\begin{array}{l}\text { Degree } \\
\text { of Sili- } \\
\text { cifica- } \\
\text { tion }\end{array}$} & \multirow[b]{3}{*}{$\begin{array}{l}\text { Abun- } \\
\text { dance } \\
\text { of Car- } \\
\text { bonate }\end{array}$} & \multirow[b]{3}{*}{ Unit } & \multirow[b]{3}{*}{$\mathrm{SiO}_{2}$} & \multirow[b]{3}{*}{$\mathrm{Al}_{2} \mathrm{O}_{3}$} & \multirow[b]{3}{*}{$\mathrm{Fe}_{2} \mathrm{O}_{3}$} & \multirow[b]{3}{*}{$\mathbf{K}_{2} \mathbf{O}$} & \multirow{2}{*}{\multicolumn{2}{|c|}{ Sulfide }} & \multirow[b]{3}{*}{$\begin{array}{l}\text { Au } \\
(\mathbf{p p b})\end{array}$} & \multicolumn{2}{|c|}{$\begin{array}{l}\text { Calculated } \\
\text { Values }\end{array}$} \\
\hline & & & & & & & & & & & & & & Pyrite & Excess \\
\hline & & & & & & & & & & & $\mathbf{S}$ & $\mathrm{C}_{2} 2$ & & $(w t \%)$ & $(w t \%)$ \\
\hline BZ-937-C & 16 & 1197 & ND & 2 & 1 & $\mathrm{WS} / \mathrm{SB}(\mathrm{DF})$ & 67,01 & 2,54 & 4,23 & 0,65 & 3,25 & 11,92 & 31400 & 6,03 & 63,16 \\
\hline BZ-937-C & 16 & 1203 & V & 1 & 1 & WS & 51,60 & 5,96 & 4,13 & 1,45 & 3,3 & 16,13 & 1700 & 6,12 & 42,57 \\
\hline BZ-960-C & 18 & 1192 & $\mathrm{~V}, \mathrm{H}$ & 3 & 0 & $\mathrm{WS} / \mathrm{SB}(\mathrm{RB})$ & 85,17 & 4,23 & 3,15 & 1,06 & 1,98 & 0,95 & 38000 & 3,65 & 78,76 \\
\hline BZ-960-C & 18 & 1226 & PB & 3 & 0 & WS/PB & 89,81 & 3,17 & 2,54 & 0,76 & 1,65 & 2,35 & 9260 & 3,03 & 85,01 \\
\hline BZ-965-C & 13 & 1277 & & 0 & 3 & PL & 19,25 & 3,66 & 1,58 & 1,14 & 1,21 & 30,43 & 1150 & 2,21 & 14,94 \\
\hline BZ-965-C & 13 & 1303 & & 0 & 3 & PL & 15,11 & 2,59 & 1,35 & 0,64 & 0,84 & 33,55 & 1460 & 1,52 & 11,19 \\
\hline BZ-965-C & 13 & 1397 & TB & 1 & 2 & WS/TB & 50,27 & 3,68 & 1,41 & 0,60 & 1,03 & 19,43 & 368 & 1,87 & 44,70 \\
\hline BZ-965-C & 13 & 1484 & & 2 & 0 & PL & 82,25 & 6,76 & 2,19 & 1,79 & 1,73 & 1,47 & 135 & 3,18 & 72,01 \\
\hline BZ-965-C & 13 & 1576 & & 3 & 0 & LL & 83,27 & 6,58 & 3,29 & 0,31 & 2,43 & 0,92 & 84 & 4,49 & 75,52 \\
\hline BZ-975-C & 11 & 1018 & & 1 & 1 & PL & 59,17 & 1,91 & 1,13 & 0,39 & 0,75 & 16,50 & 2200 & 1,35 & 56,28 \\
\hline BZ-975-C & 11 & 1148 & $\mathrm{~V}, \mathrm{H}$ & 0 & 2 & WS & 34,04 & 5,42 & 1,97 & 2,16 & 1,51 & 23,83 & 32 & 2,77 & 27,65 \\
\hline BZ-975-C & 11 & 1211 & $\mathrm{~V}$ & 1 & 1 & WS & 59,72 & 6,48 & 1,30 & 0,96 & 0,89 & 13,75 & 39 & 1,61 & 49,90 \\
\hline BZ-976-C & 14 & 1222 & & 0 & 2 & PL & 32,21 & 9,40 & 5,75 & 2,35 & 3,98 & 21,45 & 18000 & 7,39 & 17,97 \\
\hline BZ-976-C & 14 & 1247 & & 1 & 0 & PL & 41,67 & 1,05 & 23,10 & 0,16 & 18,86 & 9,35 & 9280 & 35,23 & 40,08 \\
\hline BZ-976-C & 14 & 1296 & ND & 3 & 0 & $\mathrm{WS} / \mathrm{DF}$ & 86,49 & 2,09 & 2,17 & 0,43 & 1,41 & 4,03 & 2720 & 2,58 & 83,32 \\
\hline BZ-976-C & 14 & 1333 & ND & 2 & 0 & $\mathrm{WS} / \mathrm{DF}$ & 82,64 & 5,47 & 3,35 & 1,46 & 2,19 & 0,18 & 33800 & 4,04 & 74,35 \\
\hline BZ-976-C & 14 & 1367 & ND & 3 & 0 & $\mathrm{WS} / \mathrm{DF}$ & 82,03 & 2,04 & 1,20 & 0,28 & 0,81 & 6,78 & 8600 & 1,46 & 78,94 \\
\hline BZ-976-C & 14 & 1481 & & 2 & 0 & LL & 82,75 & 8,08 & 1,17 & 0,36 & 0,61 & 0,37 & 326 & 1,09 & 73,23 \\
\hline BZ-980-C & 12 & 1057 & & 2 & 1 & PL & 67,19 & 2,79 & 1,09 & 0,59 & 0,84 & 11,55 & 260 & 1,52 & 62,96 \\
\hline BZ-980-C & 12 & 1214 & $\mathrm{H}$ & 1 & 2 & WS & 48,97 & 6,39 & 2,34 & 0,49 & 1,53 & 18,33 & 848 & 2,81 & 41,44 \\
\hline BZ-980-C & 12 & 1251 & $\mathrm{~KB}$ & 1 & 1 & WS KB & 66,71 & 5,45 & 2,16 & 1,40 & 1,52 & 10,63 & 3050 & 2,79 & 58,45 \\
\hline BZ-980-C & 12 & 1264 & ND & 3 & 0 & $\mathrm{WS} / \mathrm{DF}$ & 82,35 & 2,48 & 3,49 & 0,57 & 2,54 & 4,40 & 13100 & 4,70 & 78,59 \\
\hline BZ-980-C & 12 & 1329 & & 0 & 3 & LL & 32,58 & 2,67 & 1,32 & 0,70 & 0,70 & 27,50 & 807 & 1,26 & 28,54 \\
\hline BZ-995-C & 19 & 1138 & TB & 3 & 0 & WS/TB & 85,46 & 3,41 & 3,98 & 0,82 & 2,79 & 0,84 & 32200 & 5,17 & 80,29 \\
\hline BZ-995-C & 19 & 1194 & $\mathrm{HF}$ & 0 & 3 & $\mathrm{WS} / \mathrm{HF}$ & 19,49 & 5,73 & 4,28 & 0,59 & 1,52 & 30,43 & 42000 & 2,79 & 12,74 \\
\hline BZ-996-C & 17 & 902 & KB & 0 & 2 & $\mathrm{WS} / \mathrm{KB}$ & 43,04 & 4,88 & 2,90 & 1,32 & 1,76 & 20,35 & 50800 & 3,24 & 35,65 \\
\hline BZ-996-C & 17 & 913 & V & 1 & 2 & WS/SB(DF) & 46,59 & 3,40 & 2,48 & 0,86 & 1,47 & 21,08 & 24300 & 2,70 & 41,44 \\
\hline BZ-997-C & 20 & 825 & & 2 & 1 & PL & 65,39 & 2,96 & 1,05 & 0,79 & 0,72 & 11,37 & 38 & 1,29 & 60,91 \\
\hline BZ-997-C & 20 & 939 & ND & 0 & 2 & WS & 49,98 & 7,20 & 2,70 & 1,95 & 1,83 & 17,05 & 870 & 3,37 & 39,07 \\
\hline BZ-997-C & 20 & 953 & & 0 & 0 & WS & 84,91 & 5,03 & 1,57 & 1,45 & 1,20 & 2,20 & 4540 & 2,19 & 77,29 \\
\hline BZ-997-C & 20 & 1613 & & 1 & 1 & LL & 65,50 & 5,26 & 0,95 & 0,68 & 0,67 & 11,73 & 35 & 1,20 & 57,53 \\
\hline BZ-998-C & 21 & 809 & & 1 & 2 & PL & 52,87 & 4,56 & 1,63 & 1,60 & 1,30 & 15,40 & 42 & 2,38 & 47,50 \\
\hline BZ-998-C & 21 & 1012 & $\mathrm{~V}, \mathrm{H}$ & 0 & 3 & WS & 30,96 & 3,05 & 0,73 & 0,21 & 0,40 & 28,05 & 42 & 0,69 & 27,37 \\
\hline BZ-998-C & 21 & 1112 & ND & 3 & 0 & WS & 86,34 & 7,04 & 0,76 & 0,38 & 0,57 & 0,92 & 40 & 1,01 & 78,05 \\
\hline BZ-998-C & 21 & 1136 & I & 3 & 0 & WS/SB(DF) & 85,41 & 6,18 & 1,41 & 0,99 & 1,06 & 0,73 & 42 & 1,93 & 76,05 \\
\hline BZ-998-C & 21 & 1341 & & 0 & 2 & LL & 40,25 & 5,90 & 1,63 & 1,56 & 0,39 & 19,80 & 18 & 0,68 & 31,31 \\
\hline CD-12-C & 25 & 1085 & $\mathrm{~V}, \mathrm{H}$ & 0 & 2 & WS(deca.) & 44,26 & 5,82 & 2,15 & 2,01 & 1,19 & 19,98 & 27 & 2,17 & 37,40 \\
\hline CD-12-C & 25 & 1103 & ND & 0 & 2 & WS & 40,64 & 6,04 & 1,84 & 2,11 & 0,7 & 21,27 & 14 & 1,26 & 33,52 \\
\hline CD-12-C & 25 & 1152 & V & 0 & 2 & WS & 48,39 & 7,17 & 2,41 & 2,33 & 0,97 & 16,87 & 16 & 1,76 & 39,94 \\
\hline CD-18-C & 26 & 1091 & $\mathrm{~V}, \mathrm{I}$ & 1 & 2 & $\mathrm{WS} / \mathrm{DF}$ & 46,19 & 4,46 & 1,71 & 1,43 & 0,83 & 21,63 & 7 & 1,50 & 40,94 \\
\hline CD-19-C & 27 & 1682 & $\mathrm{~V}$ & 0 & 2 & WS(unalt.) & 34,95 & 5,10 & 1,99 & 1,71 & 0,61 & 24,75 & 7 & 1,09 & 28,94 \\
\hline CD-19-C & 27 & 1781 & $\mathrm{~V}, \mathrm{I}$ & 0 & 2 & WS(unalt.) & 49,16 & 6,55 & 1,79 & 1,75 & 0,66 & 17,78 & 14 & 1,18 & 39,24 \\
\hline GA-47 & 23 & 1485 & & 1 & 1 & PL & 62,45 & 2,99 & 1,01 & 0,63 & 0,80 & 13,57 & 380 & 1,44 & 57,92 \\
\hline
\end{tabular}




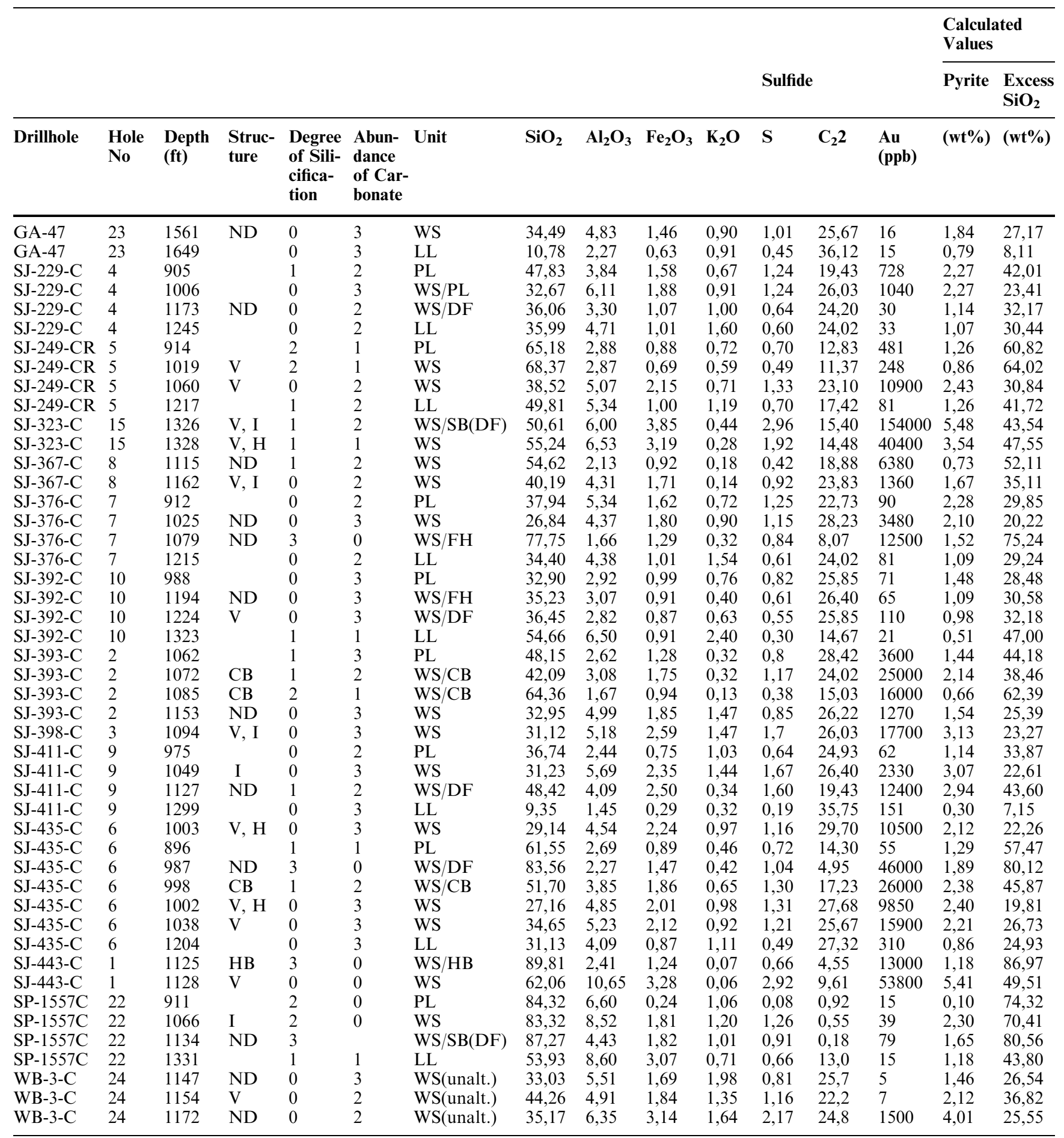

\section{References}

Arehart GB (1996) Characteristics and origin of sediment-hosted disseminated gold deposits: a review. Ore Geol Rev 11:383403

Arehart GB, Foland KA, Nasser CW, Kesler SE (1993) ${ }^{40} \mathrm{Ar} /{ }^{39} \mathrm{Ar}$, $\mathrm{K} / \mathrm{Ar}$ and fission track geochronology of sediment-hosted disseminated gold deposits at Post-Betze, Carlin Trend, Northeastern Nevada. Econ Geol 88:622-646
Armstrong AK, Theodore TG, Kotlyar BB, Lauha EG, Griffin GL, Lorge DL, Abbott EW (1997) Preliminary facies analysis of Devonian autochthonous rocks that host gold along the Carlin Trend, Nevada. In: Vikre P, Thompson TP, Bettles $\mathrm{K}$, Christensen O, Parratt R (eds) Carlin-type gold deposits field conference. Society of Economic Geologists Field Trip Guidebook Series, vol 28. Society of Economic Geologists, Littleton, CO, pp 53-74

Barin I (1995) Thermochemical data of pure substances, vol 2, 3rd edn. VCH, New York 
Barton PB Jr (1969) Thermochemical study of the system Fe-As-S. Geochim Cosmochim Acta 33:841-857

Bettles KH (1989) Gold deposits of the Goldstrike mine, Carlin trend, Nevada. Society Mining Engineers Preprint 89-158

Drewes-Armitage SP, Romberger SB, Whitney CG (1996) Clay alteration and gold deposition in the Genesis and Blue Star deposits, Eureka County, Nevada, Econ Geol 91:1383-1393

Emsbo P (2000) Gold in sedex deposits. Rev Econ Geol 13:427-437

Emsbo P, Hofstra AH, Park D, Zimmerman JM, Snee L (1996) A mid-Tertiary age constraint on alteration and mineralization in igneous dikes on the Goldstrike property, Carlin trend, Nevada. Geol Soc Am Abstr Program 28(7):A476

Emsbo P, Hofstra AH, Volk JA, Lauha EA (1998) Genesis of highgrade Carlin-type gold ore at the Meikle deposit, Carlin trend, Nevada (abstr). Giant ore deposits symposium, Society of Economic Geologists, Northwest Mining Convention, Spokane, WA, pp 31-32

Emsbo P, Hutchinson RW, Hofstra AH, Volk JA, Bettles KH, Baschuk GJ, Johnson CA (1999) Syngenetic Au on the Carlin trend: implications for Carlin-type deposits. Geology 27:59-62

Emsbo P, Hofstra AH, Lauha EA (2000) Jurassic auriferous polymetallic mineralization at the Goldstrike mine, Carlin trend, Nevada. Geology and ore deposits 2000, Great Basin and Beyond Symposium, Geological Society of Nevada, RenoSparks, Nevada, May

Ferdock GC, Castor SB, Leonardson RW, Collins T (1997) Mineralogy and paragenesis of ore stage mineralization in the Betze Gold Deposit, Goldstrike mine, Eureka county, Nevada. In: Vikre P, Thompson TP, Bettles K, Christensen O, Parratt R (eds) Carlin-type gold deposits field conference. Society of Economic Geologists Field Trip Guidebook Series, vol 28. Society of Economic Geologists, Littleton, CO, pp 3-38

Folger HW, Hofstra AH, Eberl DD, Snee LW (1998) Importance of clay characterization to interpretation of $40 \mathrm{Ar} / 39 \mathrm{Ar}$ dates on illite from Carlin-type gold deposits: insights from Jerritt Canyon, Nevada. US Geological Survey Open File Report 98338, pp 193-201

Fortuna J, Kesler SE, Ye Z, Alt JC, Core DP, Zohar P, Borhauer J, Chryssoulis SL (2003) Evaluation of sulfidation in Carlin-type gold deposits. Econ Geol Spec Issue (in press)

Graney JR, Kesler SE, Jones HD (1991) Application of gas analysis of jasperoid inclusion fluids to exploration for micron gold deposits. J Geochem Explor 42:91-106

Haynes FM (1984) Vein densities in drill core, Sierrita porphyry copper deposit, Pima County, Arizona. Econ Geol 79:755-758

Haynes FM, Titley SR (1980) The evolution of fracture-related permeability within the Ruby Star granodiorite, Sierrita porphyry copper deposit, Pima County, Arizona. Econ Geol 75:673-683

Hofstra AH, Cline JS (2000) Characteristics and models for Carlintype gold deposits. Rev Econ Geol 13:163-220

Hofstra AH, Leventhal JS, Northrop HR, Landis GP, Rye RO, Birak DJ, Dahl AR (1991) Genesis of sediment-hosted disseminated gold deposits by fluid mixing and sulfidation: chemical reaction path modeling of ore-depositional processes documented in the Jerritt Canyon district, Nevada. Geology 19:36-40

Holland R, Powell T (1998) An internally consistent thermodynamic data set for phases of petrological interest. J Metamorph Geol 16:309-343

Kissin SA, Scott SD (1982) Phase relations involving pyrrhotite below $350{ }^{\circ} \mathrm{C}$. Econ Geol 77:1739-1754

Kuehn CA, Rose AW (1992) Geology and geochemistry of wallrock alteration at the Carlin gold deposit, Nevada. Econ Geol $87: 1697-1721$

Leonardson RW, Rahn JE (1996) Geology of the Betze-Post gold deposits, Eureka county, Nevada. In: Coyner AR, Fahey PL (eds) Geology and ore deposits of the American Cordillera.
Geological Society of Nevada Symposium Proceedings, Reno/ Sparks, Nevada, April 1995, pp 61-94

Malinin SD (1974) Thermodynamics of the $\mathrm{H}_{2} \mathrm{O}-\mathrm{CO}_{2}$ system. Geochem Int 10:1060-1085

Ohle EL (1985) Breccias in Mississippi Valley-type deposits. Econ Geol 80:1736-1752

Peters SG, Leonardson RW, Ferdock GC, Lauha EA (1997) Breccia types in the Betze orebody, Goldstrike mine, Eureka county, Nevada. In: Vikre P, Thompson TP, Bettles K, Christensen O, Parratt R (eds) Carlin-type gold deposits field conference. Society of Economic Geologists Field Trip Guidebook Series, vol 28. Society of Economic Geologists, Littleton, CO, pp $87-100$

Ressel MW, Noble DC, Henry CD, Trudel WS (2000) Dike-hosted ores of the Beast deposit and importance of Eocene magmatism in gold mineralization of the Carlin trend, Nevada. Econ Geol 95:1417-1444

Roberts RJ, Hotz PE, Gilluly J, Ferguson HG (1958) Paleozoic rocks in north-central Nevada. Am Assoc Petrol Geol Bull 66:14-33

Robie RA, Hemingway BS (1995) Thermodynamic properties of minerals and related substances at $298.15 \mathrm{~K}$ and 1 bar pressure and at higher temperatures. US Geol Surv Bull no B2131

Sangster DF (1988) Breccia-hosted lead-zinc deposits in carbonate rocks. In: James NP, Choquette PW (eds) Paleokarst. Springer, Berlin Heidelberg New York, pp 102-116

Sillitoe RH (1985) Ore-related breccias in volcano-plutonic arcs Econ Geol 80:1467-1514

Simon G, Kesler SE, Chryssoulis S (1999) Geochemistry and textures of gold-bearing arsenian pyrite, Twin Creeks, Nevada: implications for deposition of gold in Carlin-type deposits. Econ Geol 94:405-421

Spycher NF, Reed MH (1988) Fugacity coefficients of $\mathrm{H}_{2}, \mathrm{CO}_{2}$, $\mathrm{CH}_{4}, \mathrm{H}_{2} \mathrm{O}$ and of $\mathrm{H}_{2} \mathrm{O}-\mathrm{CO}_{2}-\mathrm{CH}_{4}$ mixtures: a virial equation treatment for moderate pressures and temperatures applicable to calculations of hydrothermal boiling. Geochim Cosmochim Acta 52:739-749

Stenger DP, Kesler SE, Peltonen D, Tapper C (1998) Deposition of gold in Carlin-type deposits: the role of sulfidation and decarbonatization in Twin Creeks, Nevada. Econ Geol 93:201-215

Takenouchi S, Kennedy GC (1964) The binary system $\mathrm{H}_{2} \mathrm{O}-\mathrm{CO}_{2}$ at high temperatures and pressures. Am J Sci 262:1055-1074

Teal L, Jackson M (1997) Geologic overview of the Carlin Trend Gold Deposit and description of recent deep discoveries. In: Vikre P, Thompson TP, Bettles K, Christensen O, Parratt R (eds) Carlin-type gold deposits field conference. Soc Econ Geol Field Trip Guidebook Ser 28:3-38

Theodore TG, Armstrong AK, Harris AG, Stevens CH, Tosdal RM (1998) Geology of the northern terminus of the Carlin trend, Nevada: links between crustal shortening during the Late Paleozoic Humboldt orogeny and northeast-striking faults. US Geological Survey Open-file report 98-338

Tosdal RM, Nutt CJ (1999) Late Eocene and Oligocene tectonic setting of Carlin-type Au deposits, Carlin trend, Nevada, USA. In: Stanley CJ, Alderton RH (eds) Mineral deposits: processes to processing. Balkema, Rotterdam, pp 905-908

Vaughan DJ, Craig JR (1997) Sulfide ore mineral stabilities, morphologies, and intergrowth textures. In: Barnes HL (ed) Geochemistry of hydrothermal ore deposits. Wiley, Chichester, pp 367-390

Volk JA, Lauha E, Leonardson RW, Rahn JE (1996) Roadlog for Trip B; structural geology of Carlin Trend; structural geology of the Betze-Post and Meikle deposits, Elko and Eureka counties, Nevada. In: Green SM, Struhsacker E (eds) Geology and ore deposits of the American Cordillera; field trip guidebook compendium. Geological Society of Nevada, Reno, pp 180-194 